\title{
Comparison between Polybutylcyanoacrylate Nanoparticles with Either Surface-Adsorbed or Encapsulated Brain-Derived Neurotrophic Factor on the Neural Differentiation of iPSCs
}

\author{
Martin Hsiu-Chu Lin ${ }^{1,+}{ }^{,}$Chiu-Yen Chung ${ }^{1,+}{ }^{+}$, Kuo-Tai Chen ${ }^{1}$, Jih-Chao Yeh ${ }^{2,3}$, \\ Tsong-Hai Lee ${ }^{2,4}$, Ming-Hsueh Lee ${ }^{1}$, I-Neng Lee ${ }^{5}$, Wei-Chao Huang ${ }^{1}$ and Jen-Tsung Yang ${ }^{1,4, *}$ \\ 1 Department of Neurosurgery, Chang Gung Memorial Hospital, Chiayi 61363, Taiwan; \\ martinhclin@hotmail.com (M.H.-C.L.); yen5103106@gmail.com (C.-Y.C.); tad9116@cgmh.org.tw (K.-T.C.); \\ ming2072@cgmh.org.tw (M.-H.L.); u9201031@gmail.com (W.-C.H.) \\ 2 Stroke Center and Department of Neurology, Linkou Chang Gung Memorial Hospital, Taoyuan 33305, \\ Taiwan; Jihchao@gmail.com (J.-C.Y.); thlee@cgmh.org.tw (T.-H.L.) \\ 3 Department of Urology at the University of Southern California, Los Angeles, CA 90033, USA \\ 4 College of Medicine, Chang Gung University, Taoyuan 333, Taiwan \\ 5 Department of Medical Research, Chang Gung Memorial Hospital, Chiayi 61363, Taiwan; \\ geneasylum@yahoo.com.tw \\ * Correspondence: jents716@ms32.hinet.net; Tel.: +886-05-362-1000 (ext. 3996) \\ + These authors contributed equally to this work.
}

Received: 30 November 2018; Accepted: 31 December 2018; Published: 6 January 2019

\begin{abstract}
The brain-derived neurotrophic factor (BDNF) is vital in the neural differentiation of neural stem/progenitor cells, and together may have therapeutic potential for neural regeneration. In this study, a multiplexed polybutylcyanoacrylate nanoparticle (PBCA NP) delivery platform was constructed, incorporating either surface-adsorbed or encapsulated BDNF for the induction of neural differentiation in induced pleuripotent stem cells (iPSCs), where tween 80 (T80) and superparamagnetic iron oxide (SPIO) were added for central nervous system (CNS) targeting and magnetic resonance (MR) image tracking, respectively. Both methods by which the BDNF was carried resulted in loading efficiencies greater than $95 \%$. The nanoparticle-mediated delivery of BDNF resulted in neural differentiation of iPSCs detected on immunofluorescence staining as early as 7 days, with enhanced differentiation efficiency by 1.3-fold compared to the control on flow cytometry; the delivery system of surface-adsorbed BDNF gave rise to cells that had the best neural development than the encapsulated formulation. T80-coating disrupted the in vitro blood-brain barrier model with a corresponding 1.5- to two-fold increase in permeability. SPIO-loaded PBCA NPs exhibited a concentration-dependent, rapid decay in signal intensity on the phantom MR experiment. This study demonstrates the versatility of the PBCA NP, and the surface-adsorption of BDNF is the preferred method of delivery for the differentiation of iPSCs.
\end{abstract}

Keywords: brain-derived neurotrophic factor; polybutylcyanoacrylate nanoparticles; superparamagnetic iron oxide; induced pluripotent stem cell

\section{Introduction}

Healing by regeneration of the damaged tissue requires either the direct repair or replacement of the damaged cells by specialized tissue-specific resident stem/progenitor cells [1]. In the central nervous system (CNS), the regenerative capacity following injury or disease is limited, thus it often translates to suboptimal neurologic recovery and poses a unique set of challenges from a therapeutic 
point of view. In spite of the fact that many regions in the mammalian CNS are known to harbor neural stem cells [2-7], and the role that these resident stem cells play in homeostasis and repair, the imbalance of growth-inhibiting and promoting cues [8,9], the non-permissive microenvironment outside the neurogenic region [10], neuro-inflammation [11], and the age-related signal alteration in the stem cell niche with the associated decline in the stem cell pool, all serve to hinder the regenerative process in the CNS $[12,13]$. These constraints may be resolved in part by stem/progenitor cell-replacement therapy, which not only replenishes the damaged cells by neurogenesis and gliogenesis, but also exerts a neurotrophic and immune-modulatory effect that complements the endogenous reparative mechanism [14-16].

The seemingly limitless supply of induced pluripotent stem cells (iPSCs) that can be generated by the reprogramming of somatic cells to exhibit embryonic stem cell-like self-renewal and pluripotent differentiation capabilities created new opportunities for autogenic cell replacement therapy [17-19]; however, safety concerns remain with respect to the risk of tumorigenicity and immunogenicity of the transplanted cells which occur as a result of residual iPSCs and transgene-induced genomic instability [20-22]. Though methods have been devised to eliminate residual iPSCs in the iPSC-derived product, and safer transgene-free reprogramming protocols have also been developed, a less time-consuming and labor-intensive differentiation technique is still an important requisite for the clinical application of iPSCs [23-25]. The brain-derived neurotrophic factor (BDNF) is a common ingredient for the neural differentiation of iPSCs [26,27], and it additionally is a vital trophic factor in the nervous system that maintains the structure and function of neurons, regulates synaptic transmission, and promotes the axonal regeneration and differentiation of neural precursor cells [28-30]; therefore, our goal was to create a BDNF formulation that can be used to simplify and shorten the neural differentiation process of iPSCs for cell therapy, and to simultaneously stimulate the endogenous reparative mechanism by crossing the blood-brain barrier (BBB) in a combined "protein-plus-cell" approach.

The tween 80 (T80)-coated polybutylcyanoacrylate nanoparticle (PBCA NP) is a versatile polymeric delivery system that exhibits CNS-targeting capabilities [31,32], and it has been widely studied for the delivery of various substances, including drugs, proteins, and peptides, and genes that are normally impermeable to the BBB into the CNS [33-36]. The cargos can either be carried by surface adsorption or encapsulation using the easily scalable polymerization or nano-precipitating methods under ambient conditions with the n-butylcyanoacrylate (BCA) monomer or pre-formed PBCA polymers, respectively [37]. However, the cargo-loading efficiency (LE) and release kinetics differ between surface-adsorbed and encapsulated formulations of PBCA NP, in that surface adsorption is associated with a lower cargo LE, and a rapid initial burst-release, followed by a shorter sustained-release profile, whereas nanoparticle disintegration by surface erosion and drug diffusion through the polymeric matrix of the entrapped formulation results in a longer release curve [38]; these key differences may have an impact on the effectiveness of the delivered cargo.

In this study, a multiplexed PBCA NP delivery platform was constructed to carry BDNF by either surface adsorption or encapsulation; T80-coating was added for CNS targeting, and the magnetic resonance (MR) imaging contrasting agent, superparamagnetic iron oxide (SPIO) was incorporated to facilitate simultaneous non-invasive tracking of the nanoparticles and the treated iPSCs. The synthesized PBCA NPs containing SPIO with surface-adsorbed or encapsulated BDNF, and with or without T80-coating were characterized. The ability of the nanoparticle delivery platform to cross an in vitro BBB-model of rat brain microvascular endothelial cells (RBMECs) and CTX TNA2 (rat astrocyte), and neural differentiation of the exposed iPSCs were assessed. Lastly, the SPIO-tracking capability was tested in a phantom MR experiment. The nanocomposites and the proposed "protein-plus-cell" approach are summarized in Scheme 1. 
Nanoparticle construct

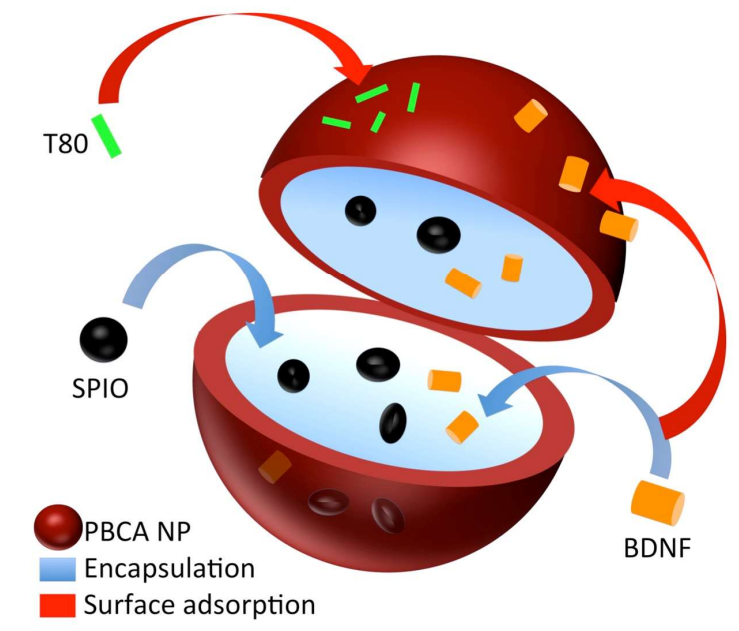

Nanoparticle Formulations

Encapsulation System

T80-PBCA-BDNF-SPIO NP

PBCA-BDNF-SPIO NP

Adsorption System

T80-BDNF-PBCA-SPIO NP

BDNF-PBCA-SPIO NP
Core

SPIO + BDNF

$\mathrm{SPIO}+\mathrm{BDNF}$

(n)

\section{Therapeutic Approach}

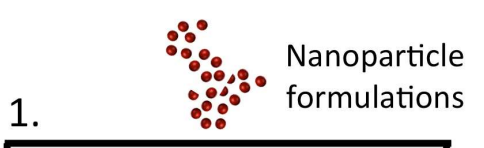

$\sqrt{ }$

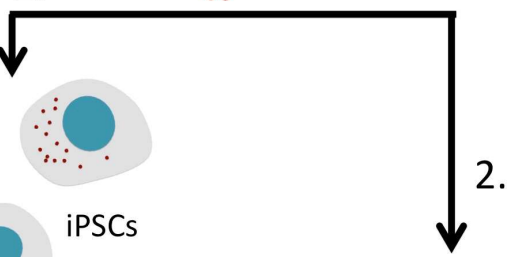

$\therefore$
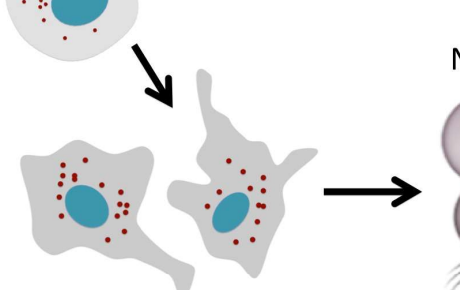

Neural repair

Neural stem / Progenitor cells

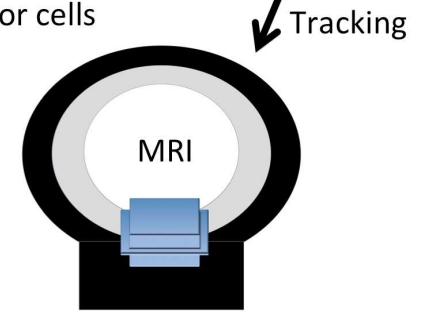

Scheme 1. The multiplexed polybutylcyanoacrylate nanoparticle (PBCA NP) delivery platform consists of several components; the brain-derived neurotrophic factor (BDNF) is the inductive agent for neural differentiation of induced pleuripotent stem cells (iPSCs), tween 80 (T80) is the surfactant necessary for enhanced penetrability through to the blood-brain barrier (BBB) into the central nervous system (CNS), and superparamagnetic iron oxide (SPIO) is the tracking agent for magnetic resonance (MR) imaging. The blue and red arrows represent loading of substances by encapsulation and surface absorption respectively. The encapsulation system of BDNF with and without T80 coating is denoted by T80-PBCA-BDNF-SPIO NP, and PBCA-BDNF-SPIO NP; and the adsorption system of BDNF with and without T80-coating is denoted by T80-BDNF-PBCA-SPIO NP and BDNF-PBCA-SPIO NP. The "protein-plus-cell" approach involves: (1) the administration of neural stem/progenitor cells derived from the nanoparticle-mediated differentiation of iPSCs as a source of cell replacement therapy, and (2) continual treatment with the BDNF-containing nanoparticles to support the reparative process in the CNS, both of which can be tracked by MR imaging.

\section{Results}

\subsection{Characterization of the Nanoparticles}

The particle size and zeta potential measured by the Zetasizer Nano ZS90, and the calculated LEs of SPIO and BDNF for the four types of nanoparticles are shown in Table 1. The effect of surface coating by $0.01 \% w / v$ of T80 on particle size was negligible for both the surface-adsorbed and encapsulated systems of BDNF, while surface adsorption of BDNF on the nanoparticle was responsible for an increased mean diameter from 125 to $150 \mathrm{~nm}$. Modification of the PBCA NPs by T80 and BDNF did not alter the zeta potential, which essentially remained slightly negative to neutral. The fabrication method by acid emulsion polymerization yielded mono-dispersed samples. The preparations that contained T80 were associated with higher SPIO LEs of up to 15\%, whereas LEs of greater than $95 \%$ were observed for BDNF regardless of its physical location. 
Table 1. The average diameter (Dav), zeta potential, polydispersity index (PDI), and loading efficiencies of BDNF and SPIO for the four types of nanoparticles.

\begin{tabular}{cccccc}
\hline Sample & \multirow{2}{*}{ Dav $(\mathbf{n m})$} & Zeta Potential $(\mathbf{m V})$ & \multirow{2}{*}{ PDI } & \multicolumn{2}{c}{ Loading Efficiency (\%) } \\
\cline { 5 - 6 } & & & & SPIO & BDNF \\
\hline PBCA-BDNF-SPIO NP & $125.2 \pm 3.2$ & $-1.3 \pm 0.3$ & $0.17 \pm 0.01$ & 10.96 & 100 \\
T80-PBCA-BDNF-SPIO NP & $124.5 \pm 0.8$ & $-0.2 \pm 1.0$ & $0.13 \pm 0.04$ & 15.32 & 100 \\
BDNF-PBCA-SPIO NP & $148.7 \pm 0.4$ & $-0.4 \pm 0.2$ & $0.12 \pm 0.02$ & 7.78 & $98.29 \pm 0.16$ \\
T80-BDNF-PBCA-SPIO NP & $146.7 \pm 1.1$ & $-1.4 \pm 0.1$ & $0.13 \pm 0.02$ & 14.16 & $98.96 \pm 0.33$ \\
\hline
\end{tabular}

The field emission scanning electron microscope (FE-SEM) images showed that the four types of PBCA NPs were spherical in shape (Figure 1), and all had a dense core, as demonstrated in the transmission electron microscope (TEM) images; in addition, and the surface texture was better resolved on the TEM, in which the surface T80 or BDNF conferred an ill-defined halo (Figure 2).
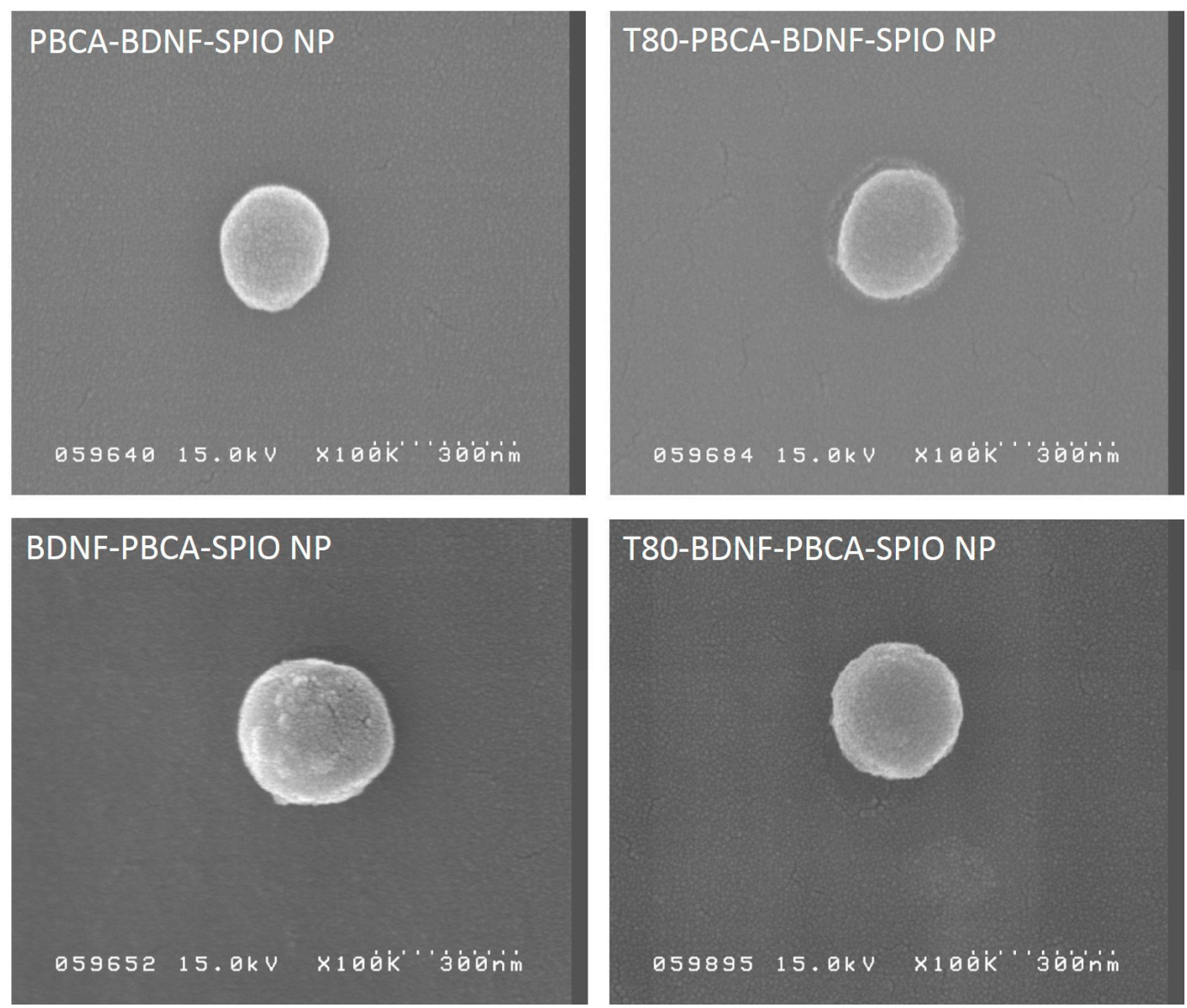

Figure 1. Field emission scanning electron microscope (FE-SEM) images of the nanoparticles at $\times 100,000$ magnification, showing how the nanoparticles are spherical in shape. 

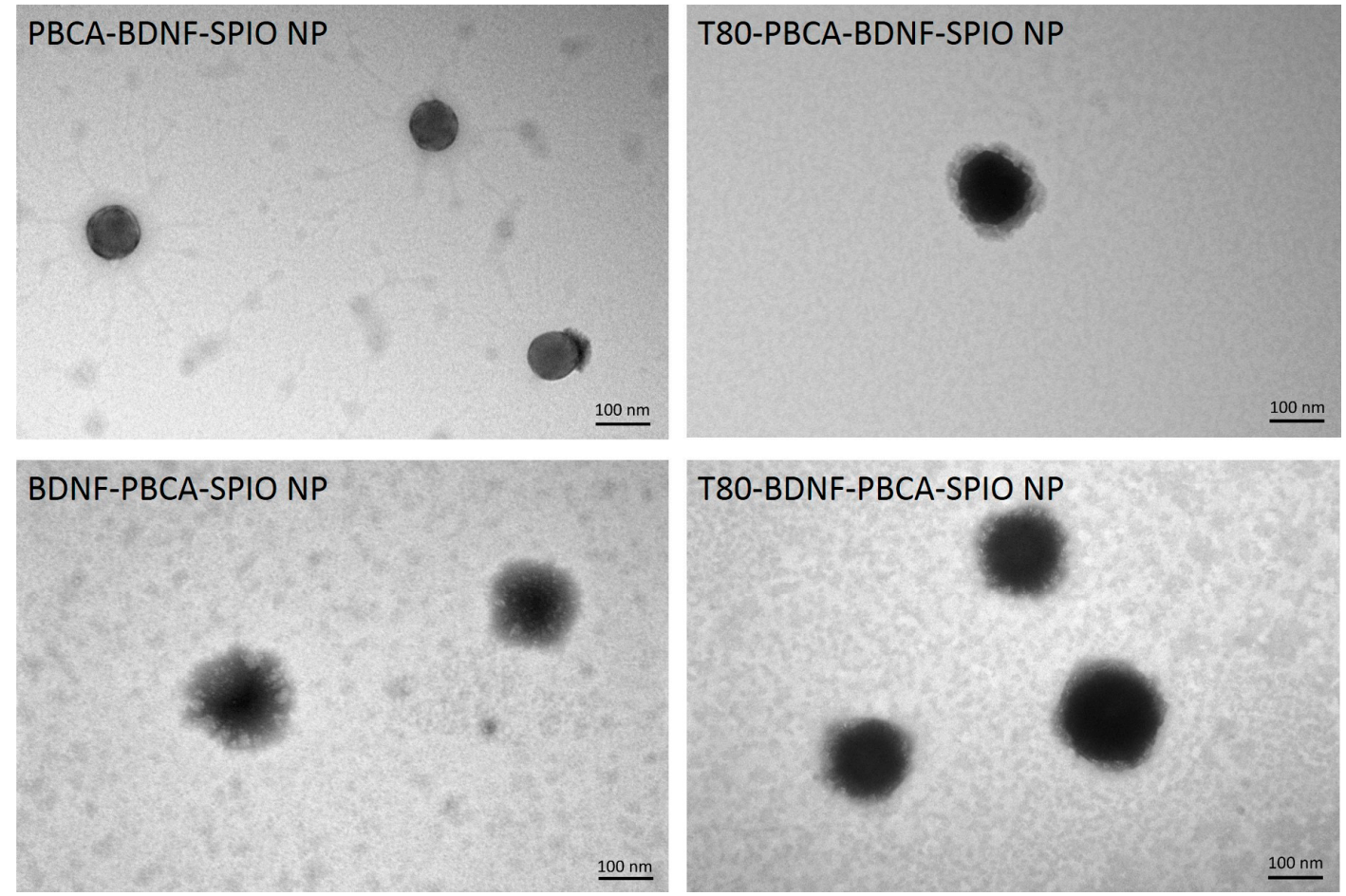

Figure 2. Transmission electron microscope (TEM) images of the nanoparticles at $\times 200,000$ magnification, showing that the nanoparticles have a dense core and an ill-defined halo that is visible for those that contain the surface-adsorbed T80 or BDNF.

\subsection{Cytotoxicity of the Nanoparticles on RBMECs, CTX TNA2, and iPSCs}

The cytotoxicity of the nanoparticles on the RBMECs, CTX TNA2, and iPSCs was determined by the XTT cell viability assay (Figure 3a-c); a concentration-dependent cytotoxicity profile was seen across the different cell types tested, with the RMBECs and CTX TNA2 exhibiting greater than $80 \%$ cell viabilities at concentrations of up to $25 \mu \mathrm{g} / \mathrm{mL}$, and double that for iPSCs. There were no significant differences in cell viabilities amongst the four types of PBCA NPs, except for iPSCs in which cytotoxicity induced by T80 was observed, but only at a high nanoparticle concentration of $100 \mu \mathrm{g} / \mathrm{mL}$. Therefore, a concentration of $25 \mu \mathrm{g} / \mathrm{mL}$ was chosen for the subsequent cell experiments.

(a)

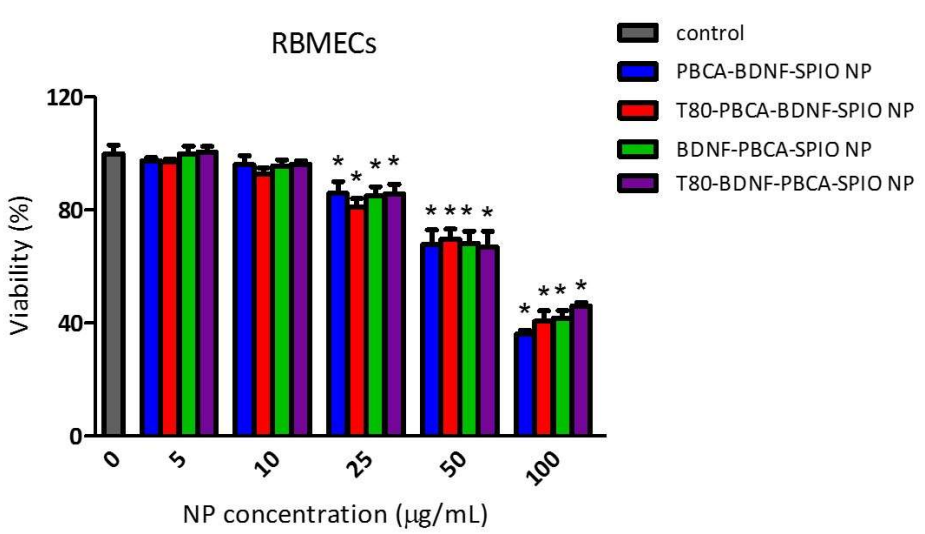

Figure 3. Cont. 
(b)

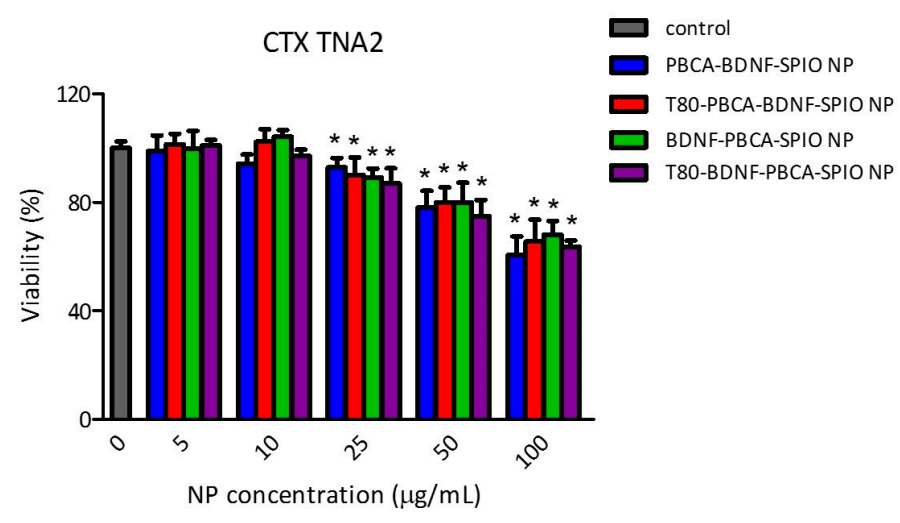

(c)

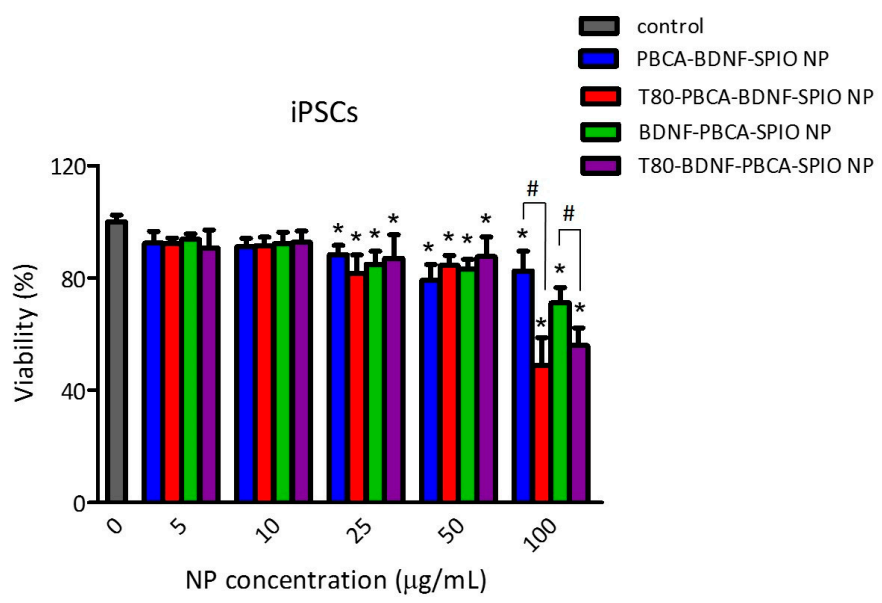

Figure 3. Cell viability determined by the XTT assay for the different PBCA NPs at the dose range of 5 to $100 \mu \mathrm{g} / \mathrm{mL}$ on (a) rat brain microvascular endothelial cells (RBMECs), (b) rat astrocyte (CTX TNA2), and (c) iPSCs. A concentration-dependent cytotoxicity profile is evident, and a concentration of up to $25 \mu \mathrm{g} / \mathrm{mL}$ appears safe for the RBMECs and CTX TNA2, and up to $50 \mu \mathrm{g} / \mathrm{mL}$ for the iPSCs. No significant differences are found in between the adsorption and encapsulation system of BDNF with and without T80 coating across the cell lines, except for the iPSCs in which T80 appears cytotoxic at a high nanoparticle concentration of $100 \mu \mathrm{g} / \mathrm{mL}$. ${ }^{*} p<0.05$ to control, ${ }^{\#} p<0.001$.

\subsection{Neural Differentiation of iPSCs Treated with the Nanoparticles}

The immunofluorescence staining for BDNF of the iPSCs exposed to BDNF alone or PBCA NPs with or without BDNF is shown in Figure $4 \mathrm{a}$, and quantification by the normalized fluorescence intensity is displayed in Figure $4 \mathrm{~b} ; 125 \mathrm{pg} / \mathrm{mL}$ of free BDNF was used for the experiment, which contained the equivalent amount of BDNF to $25 \mu \mathrm{g} / \mathrm{mL}$ of PBCA NPs carrying BDNF, assuming $100 \%$ loading and release efficiency. Similar degrees of basal BDNF expression were found in the control, PBCA-SPIO NPs, and BDNF alone, whereas treatment with the BDNF-loaded nanoparticles were associated with significant increases in BDNF; however, no appreciable differences amongst the four types of PBCA NPs were found. In addition to the staining intensity of BDNF, cells in those that had the higher level of BDNF appeared more dispersed and elongated in shape. 
(a)

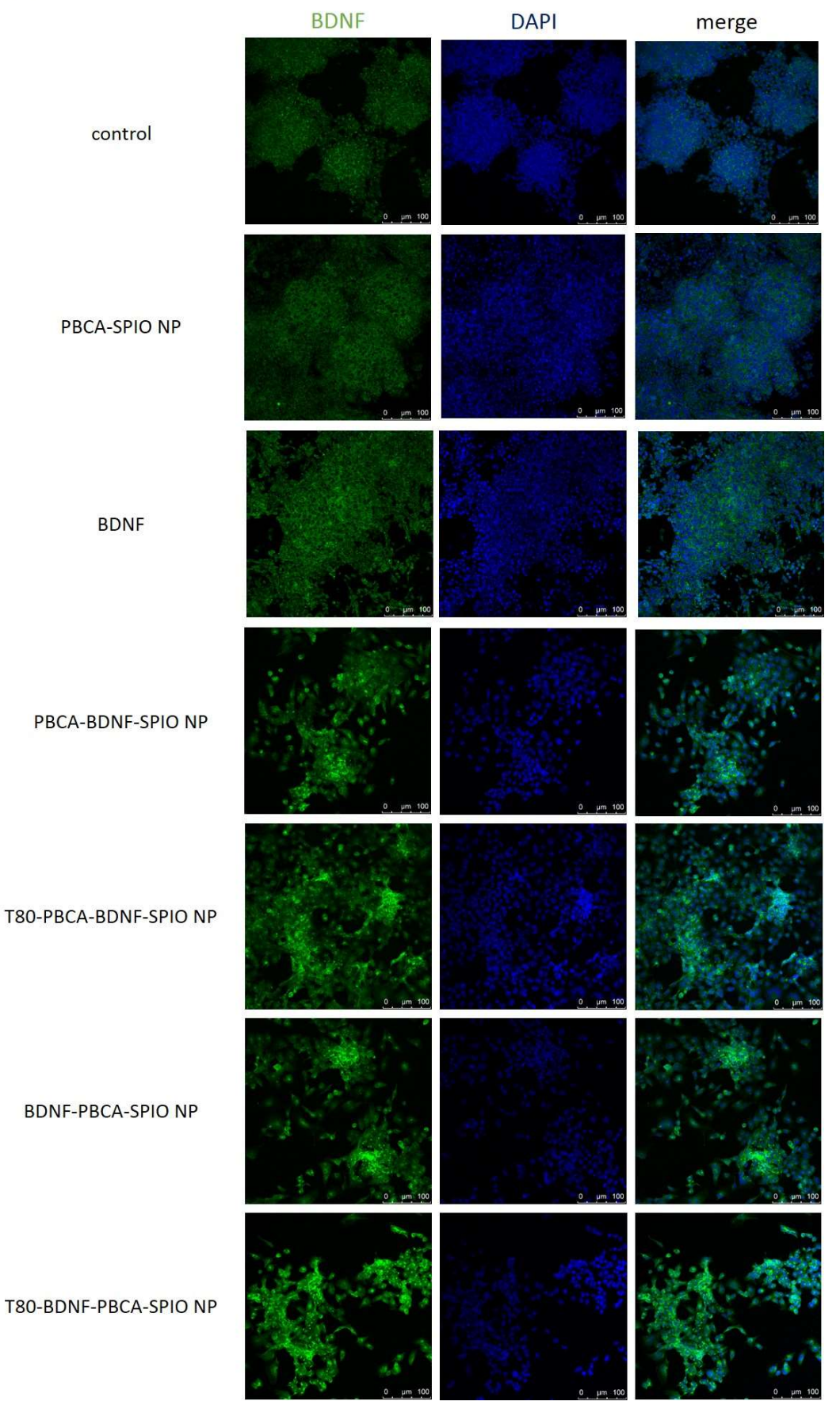

Figure 4. Cont. 
(b)

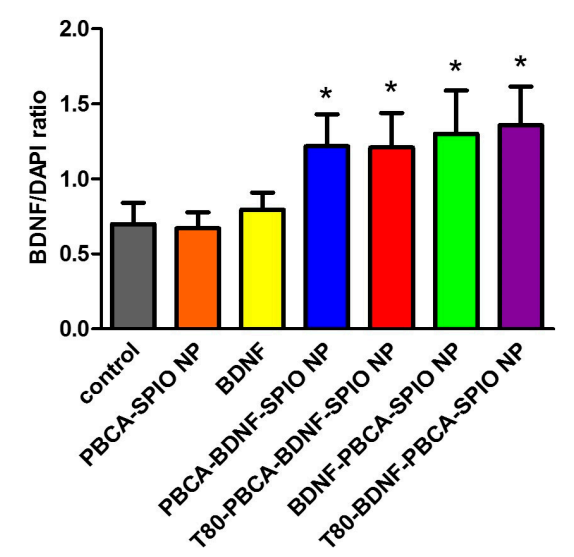

Figure 4. (a) Immunofluorescence staining at Day 7 for BDNF (green) of the iPSCs exposed to $125 \mathrm{pg} / \mathrm{mL}$ of BDNF alone or $25 \mu \mathrm{g} / \mathrm{mL}$ of nanoparticles with or without BDNF, and (b) quantification of BDNF expression by the normalized fluorescence intensity; the levels of BDNF expression appear similar for the control, PBCA-SPIO NPs, and free BDNF, where significant increases can be found for the BDNF-containing nanoparticles, which is associated with a greater dispersion of the cell cluster and elongated cell shape. ${ }^{*} p<0.05$ to control.

Neural differentiation of the iPSCs was assessed by immunofluorescence staining at Day 7 against the neural stem/progenitor cell markers, nestin and the neurofilament-heavy chain (NF H), as well as the early neural differentiation marker beta III tubulin, following exposure to free BDNF or nanoparticles with or without the loaded BDNF. Images captured by confocal microscopy are displayed in Figure 5a,b; cells that express nestin and NF H were scant in the control as well as those treated with free BDNF and PBCA-SPIO NPs, whereas numerous positively stained cells were seen when the BDNF-loaded nanoparticles were given. Likewise, the control and those treated with PBCA-SPIO NPS contained very few cells positive for beta III tubulin, and only slightly more were found with BDNF alone; moreover, cells of neural morphology could not be identified-by contrast, neural differentiation of cells treated with the BDNF-containing nanoparticles was clearly distinguishable, as these cells were not only stained strongly for beta III tubulin but also displayed a multipolar morphology, consisting of a single axon and multiple dendrites projecting from the cell body. Furthermore, a better neural differentiation was seen in cells treated with the nanoparticles that had the surface-adsorbed BDNF than the encapsulated formulation, which was associated with a greater degree of axon elongation and intercellular connections. The presence or absence of T80 coating did not appear to qualitatively influence the neuron morphology.

The flow cytometric detection of beta III tubulin-positive cells derived from the iPSCs treated with the respective nanoparticles and BDNF alone is shown in Figure $5 c$; the percentage of beta III tubulin-positive cells with PBCA-SPIO NPs was $18.8 \pm 3.9 \%$, which was similar to the control $(p=0.92)$, this percentage rose to $31.4 \pm 3.1 \%$ for BDNF only $(p<0.001)$, and $41.9 \pm 3.4 \%$ for the BDNF-containing nanoparticles, which equated to a 1.3-fold increase when compared to the control $(p<0.001)$; however, there were no significant differences amongst the different delivery systems $(p=0.303)$. 
(a)
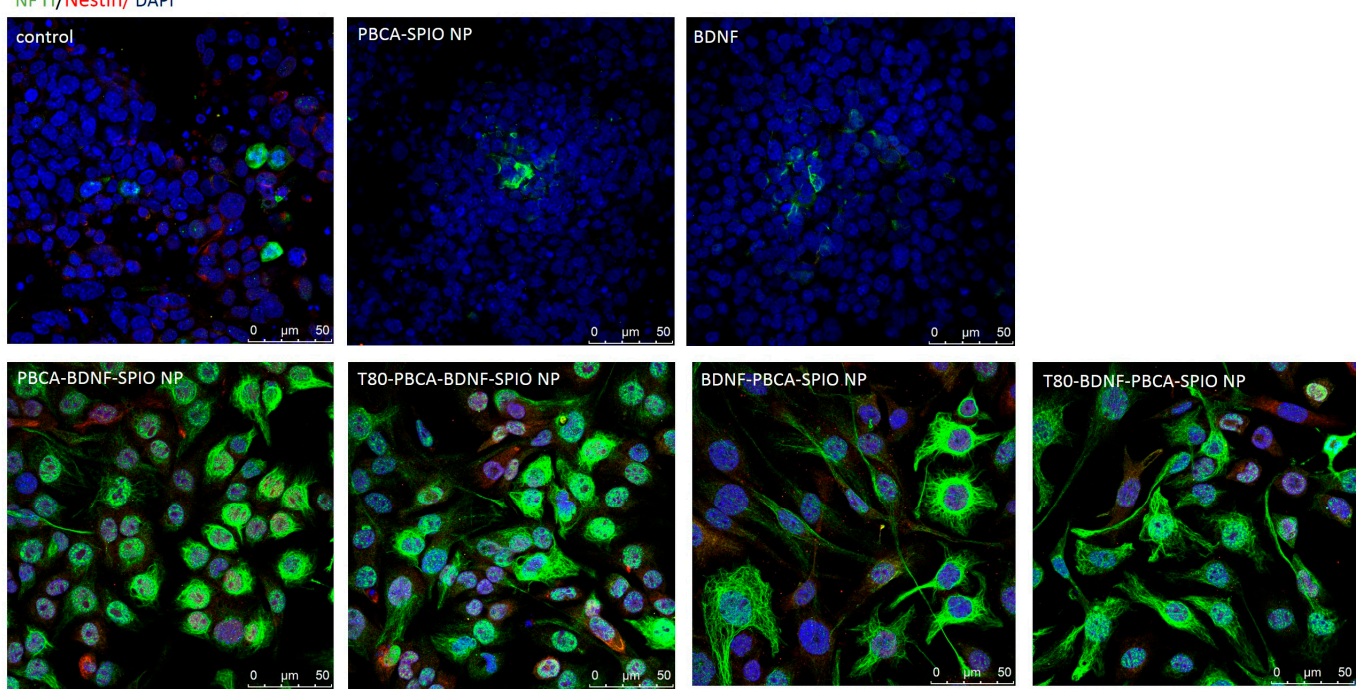

(b) beta III tubulin/DAPI
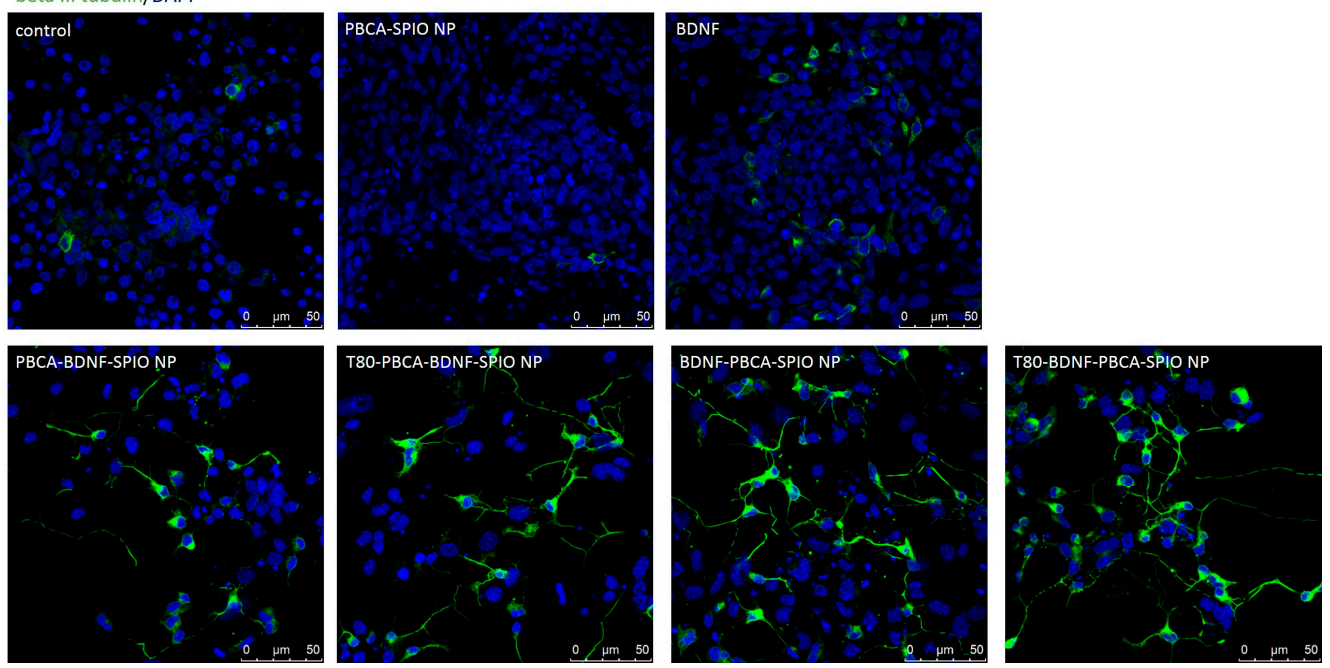

(c)
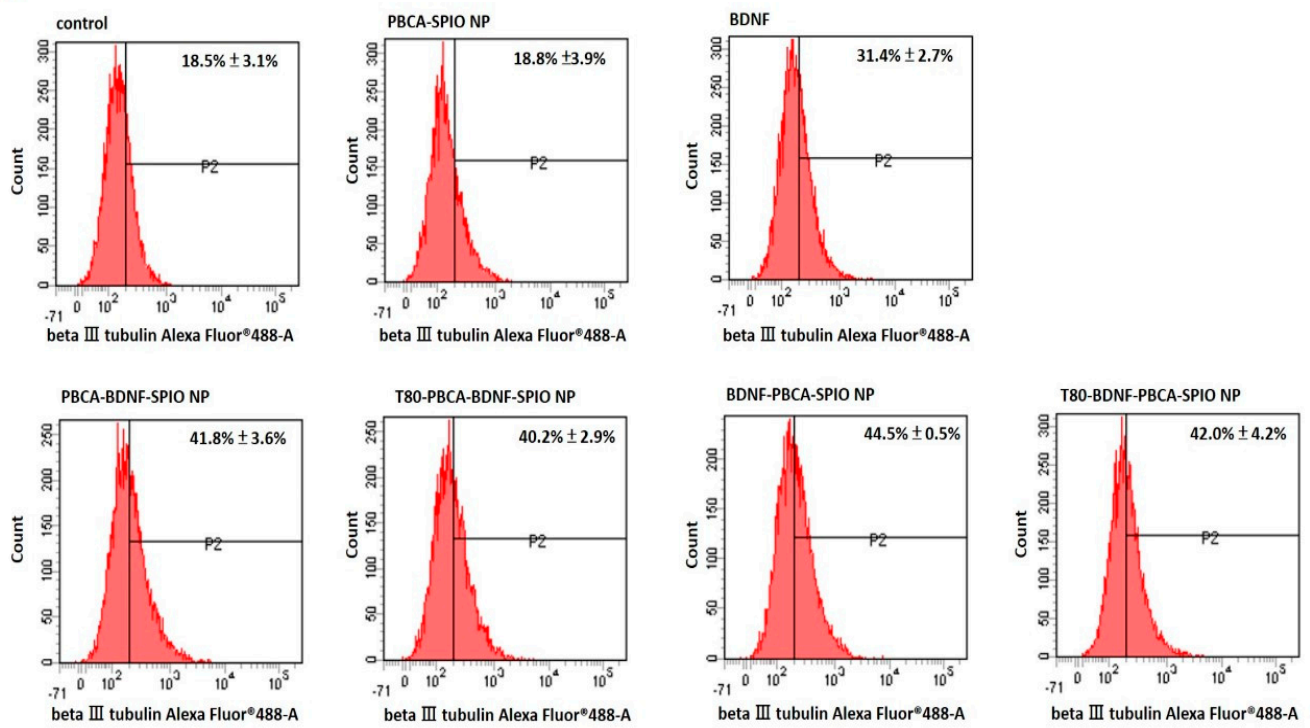

Figure 5. Immunofluorescence staining at Day 7 for (a) nestin (red) and the neurofilament-heavy chain (NF H) (green), and (b) beta III tubulin (green) on the iPSCs exposed to $125 \mathrm{pg} / \mathrm{mL}$ of free BDNF or $25 \mu \mathrm{g} / \mathrm{mL}$ of nanoparticles with or without BDNF. The control, PBCA-SPIO NPs and free BDNF, show 
a limited number of nestin and NF H-positive cells; by contrast, positively-stained cells are easily identifiable when the BDNF delivery systems are used. Similarly, the control and PBCA-SPIO NP show very few numbers of beta III tubulin-positive cells, and although it is higher with free BDNF, neural morphology cannot be found. Neural differentiation is clearly seen in cells treated with the BDNF-containing nanoparticles; furthermore, surface-adsorbed BDNF is associated with a greater degree of axon elongation and intercellular connections. (c) Flow cytometry analysis of beta III tubulin-positive cells on iPSCs exposed to free BDNF or nanoparticles; the control and PBCA-SPIO NPs show similar percentages. This percentage increases to $31.4 \pm 2.7 \%$ with free BDNF, and further increases to $41.9 \pm 3.4 \%$ with the BDNF delivery systems.

\subsection{The Effect on the Transendothelial Electrical Resistance and Permeability of the Nanoparticles across the} In Vitro Blood-Brain Barrier Model

The measured transendothelial electrical resistance (TEER) of the stabilized in vitro BBB modeled by the transwell system of contact co-cultured RBMECs and CTX TNA2 was $506.7 \pm 11.5 \Omega \mathrm{cm}^{2}$. Significant reductions in TEERs from baseline signifying disruptions on the integrity of the BBB were demonstrated when the nanoparticles were added to the RBMEC side of the system. The TEERs of the systems exposed to nanoparticles that contained surface-adsorbed or encapsulated BDNF without T80 did not differ significantly, which averaged to $426.9 \pm 19.7 \Omega \mathrm{cm}^{2}$, but an $8 \%$ reduction to $382.9 \pm 18.1 \Omega \mathrm{cm}^{2}$ was observed with T80-coated nanoparticles $(p<0.05)$ (Figure 6a).

(a)

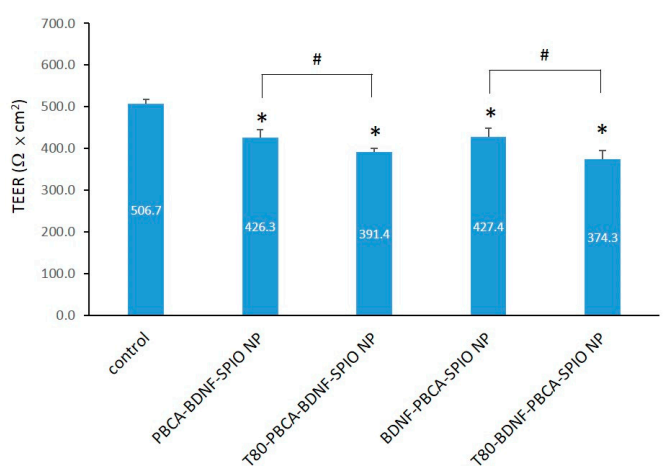

(b)

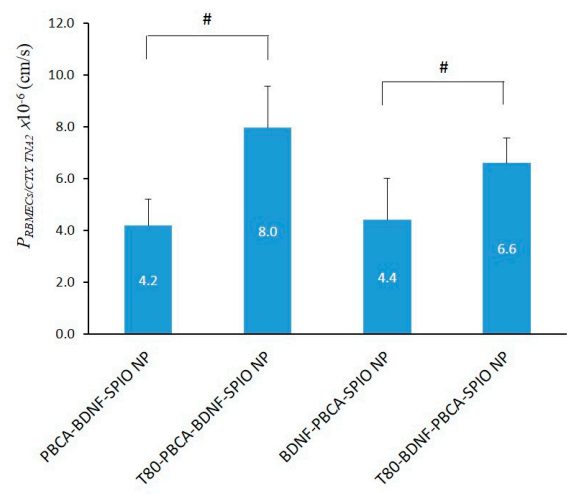

Figure 6. (a) The transendothelial electrical resistance (TEER) $\left(\Omega \mathrm{cm}^{2}\right)$ across the contact co-culture system of RBMECs and CTX TNA2 for the BDNF-containing PBCA-SPIO NPs at $25 \mu \mathrm{g} / \mathrm{mL}$ for $4 \mathrm{~h}$. The TEER of the treated cells are significantly lower than the control, and the values of the adsorption and the encapsulation system of BDNF only differ with respect to the presence and absence of T80 coating, which, on average, measures $382.9 \pm 18.1$ and $426.9 \pm 19.7 \Omega \mathrm{cm}^{2}$, respectively. (b) The permeabilities of the nanoparticles $(\mathrm{cm} / \mathrm{s})$ correspond to the degree of reduction in the TEERs, which are significantly higher with T80 coating regardless of the physical location of BDNF. ${ }^{*} p<0.05$ to control, ${ }^{\#} p<0.05$.

The permeability of the nanoparticles across the in vitro BBB model was represented by the permeability coefficient, which was quantified by the fluorescence intensity of the fluorescein isothiocyanate (FITC)-labeled nanoparticles collected on the side of the CTX TNA2 (Figure 6b). An inverse relationship of the permeability to the TEER was demonstrated; again, the permeabilities of the BDNF-containing nanoparticles only differed by the presence or absence of T80 $(7.3 \pm 1.5 \times$ $10^{-6}$ versus $\left.4.3 \pm 1.3 \times 10^{-6} \mathrm{~cm} / \mathrm{s}, p<0.001\right)$ and were not affected by the physical location of the BDNF; coating with the T80 lead to a 1.5- to 2-fold increase in permeability from baseline, and a 70\% increase when compared with the uncoated formulation. 


\subsection{Prussian Blue Staining for Detection of SPIOs}

Prussian blue staining for the detection of iron inside the iPSCs treated with the PBCA-SPIO NPs for $4 \mathrm{~h}$ is shown in Figure 7; the staining technique identified cells containing SPIOs by the precipitation of ferric iron from the SPIOs with the soluble ferrocyanide in the stain, which were characterized by the presence of solid blue deposits within the cytoplasm.
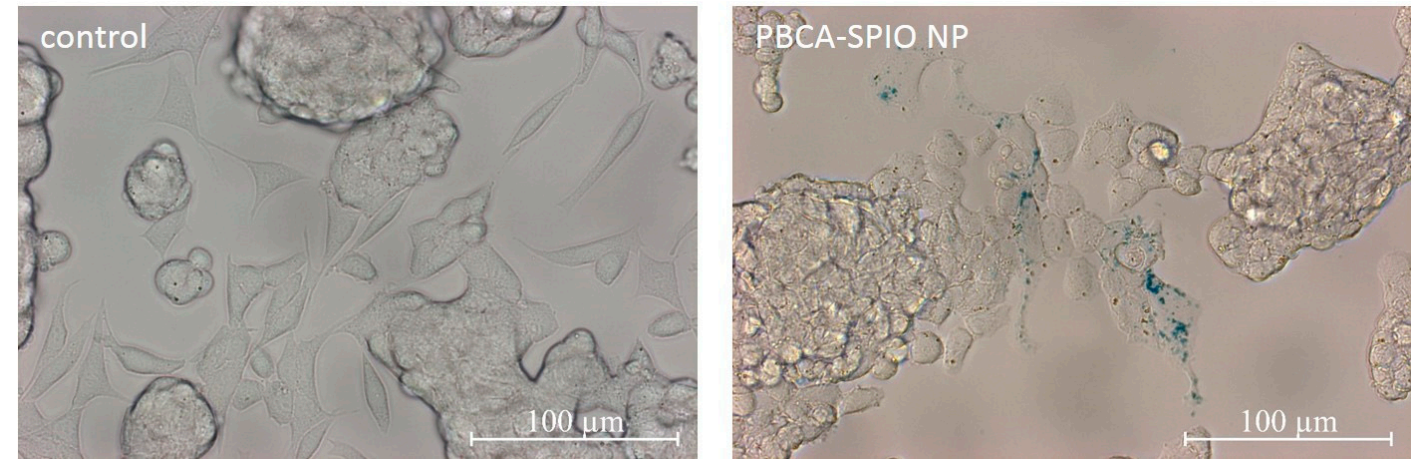

Figure 7. Prussian blue stain of iPSCs treated with $25 \mu \mathrm{g} / \mathrm{mL}$ of the PBCA-SPIO NP under $400 \times$ magnification shows cellular internalization of the SPIOs, which is visualized as small solid blue aggregates within the cell cytoplasm.

\subsection{In Vitro MR Relaxitivities of the Nanoparticles}

Phantom MR experiments were applied to investigate the magnetic property of PBCA-SPIO NPs. The MR signal intensity versus echo time (TE) at various concentrations of PBCA-SPIO NPs was plotted (Figure 8). The signal intensity and relaxitivity at a low concentration of $1 \mu \mathrm{g} / \mathrm{mL}$ was not too dissimilar from water; however, the increase in nanoparticle concentration led to a progressive decline in signal intensity, as well as a faster rate of decay.

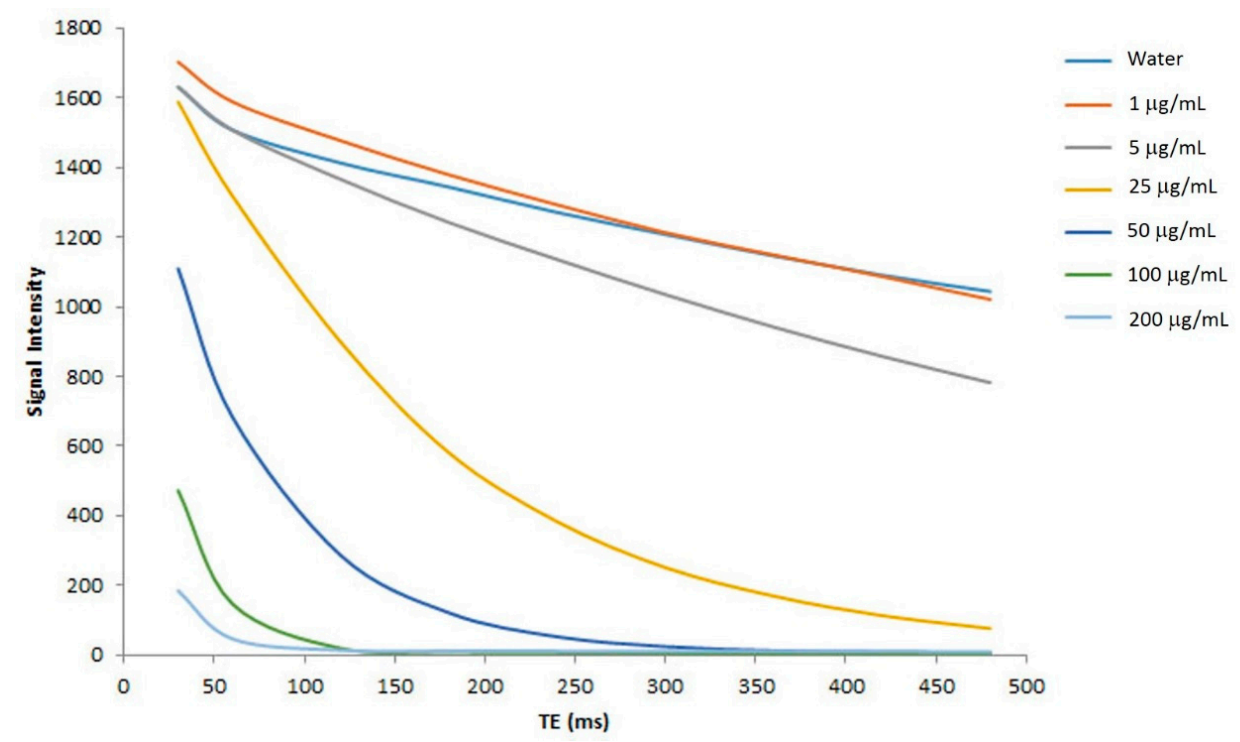

Figure 8. The phantom MR measurements of different concentrations (1 to $200 \mu \mathrm{g} / \mathrm{mL}$ ) of PBCA-SPIO NPs are represented on the signal intensity versus TE plot. The signal intensity decreases with increasing iron content (PBCA-SPIO NP concentration), and the rate of decay also becomes faster.

\section{Discussion}

A polybutylcyanoacrylate nanoparticle is a biocompatible, biodegradable synthetic polymeric drug delivery system $[39,40]$. It is the first polymer-based nanoparticle system tested to deliver drugs 
into the CNS [41]. The main building block of the PBCA NP is the BCA monomer, which polymerizes and solidifies when placed in contact with anions or radicals present on tissue surfaces or fluids [42]; thus, it is clinically approved as a topical adhesive for skin closure, as a surgical hemostatic agent, and liquid embolic agent for endovascular intervention [43-45]. PBCA NP degrades in the biological system by esterase-mediated hydrolysis of the ester side chains, which is a $\mathrm{pH}$-dependent process with half-lives that range from 144 days at $\mathrm{pH} 4$ to 3 days at $\mathrm{pH}$ 7.4; therefore, it can resist breakdown in the acidic environment of the lysosome and effectively deliver its payload into the cytosol [46,47]. PBCA NP can be modified according to clinical need; for example, PEGylation of PBCA NP evades clearance by the reticuloendothelial system, which enables increased circulation time for passive targeting and potentiates the therapeutic effect at lower doses [48]; surface coating with T80 alters the bio-distribution preferentially for the brain [49], and simultaneous loading of different substances by surface adsorption and encapsulation permits multiplexing capabilities. The loading of substances on and within the PBCA NPs is achieved sequentially; first by an incorporation step that encapsulates the desired content in the reagent mixture into the nanoparticles during the acid emulsion polymerization process, and a second incubation step by which the substance to be carried by surface adsorption is added to the solution of formed nanoparticles. These synthetic steps enable the optimal loading efficiency of BDNF for both the adsorption and the encapsulation systems; however, the use of the magnetic stirrer, coupled with a low stirring speed during the incorporation step, could reduce the available SPIO in the homogenate and lead to a low LE. Conversely, the inclusion of T80 could produce a better stabilized system of nanoparticles, and allow for the additional loading of SPIO by surface adsorption during the incubation step, thus resulting in an increased LE.

The BBB has an important regulatory function on the microenvironment of the CNS, but it also restricts entry of therapeutic substances from the circulation [50,51]. Various in vitro cell models can be used to simulate the BBB, the basic component of which comprises of the neurovascular unit made of brain capillary endothelial cells surrounded by a basement membrane, astrocytes, and pericytes [52]. The BDNF-containing nanoparticles were screened for toxicity on the cell lines that constitute the in vitro BBB model as well as on the iPSCs; a concentration of $25 \mu \mathrm{g} / \mathrm{mL}$ was considered safe for all the cell lines regardless of the presence or absence of T80 coating, and surface-adsorbed or encapsulated BDNF; notably, the iPSCs were capable of withstanding a dose of up to $100 \mu \mathrm{g} / \mathrm{mL}$, but showed additional T80 toxicity at this dose in spite of the low concentration of T80 $(0.01 \% \mathrm{w} / \mathrm{v})$ used, which was considerably less than the usual range of $0.1 \%$ to $10 \%(w / v)$ [53-56]. Although T80 is a commonly used surfactant, a previous study indicates a lethal concentration $50 \%\left(\mathrm{LC}_{50}\right)$ of $0.021 \%$ $(w / v)$ on human fibroblasts; therefore, the toxicity of T80 should not be underestimated [57]. The integrity of the BBB can be assessed by the TEER, which is a measure of the electrical resistance across the cell layer through the transcellular and paracellular pathways in parallel; the resultant TEER of $506.7 \pm 11.5 \Omega \mathrm{cm}^{2}$ in our contact co-culture system of RBMECs and CTX TNA2 is consistent with those reported in the literature [58,59], and although higher TEER in excess of $2000 \Omega \mathrm{cm}^{2}$ like those found in vivo can be achieved by increasing the complexity of the modeled system, these generally reflect on the integrity of the tight junctions; thus, values of 160 to $200 \Omega \mathrm{cm}^{2}$ or greater are generally considered adequate for BBB screening, which may be sufficient for testing nanoparticles that are too large to traverse the paracellular pathway in the presence of intact tight junctions [60-62]. The T80-coated and bare PBCA NPs have been shown to cause a transient reduction in the TEER by $80 \%$ and $50 \%$ from the baseline, respectively, and it is completely recoverable in the former but only partially in the latter. This change is attributed to an alteration in cell morphology and the organization of the neurovascular unit induced by the nanoparticles, leading to an opening of the paracellular pathway $[63,64]$. We were able to show that even at a much lower concentration of T80 $(0.01 \% w / v)$, the T80-coated formulations can still cause a small but significant decline in the TEER than those without T80 $(24 \%$ versus $16 \%, p<0.05)$. The corresponding increase in permeability of the nanoparticles across the cell layer in the transwell system was reflected proportionately to the reduction in TEER, and the inclusion of surface-adsorbed BDNF did not appear to interfere with the 
transport process. The permeability coefficients of the nanoparticles were within range of the typical transwell assay, which are in the order of $10^{-7}$ to $10^{-3} \mathrm{~cm} / \mathrm{s}$, and are beyond the threshold of 1.5 to $2.0 \times 10^{-7} \mathrm{~cm} / \mathrm{s}$ recommended for CNS therapeutics $[65,66]$. Transport of PBCA NPs across the BBB may take place via the transcellular pathway, which is believed to be the main route of transport; however, the subsequent loosening of tight junctions may also accommodate for transport through the paracellular pathway. The transcellular route is mediated by ligand-receptor interaction; the surface of these T80-coated nanoparticles may act as anchor points for apolipoproteins, and these apolipoprotein-nanoparticle complexes are then taken up by brain capillary endothelial cells through the interaction with lipoprotein receptor or lipoprotein receptor-related proteins on the luminal surface of the plasma membrane [32,67]. Alternatively, T80 may boost the fixed charge density on the surface of nanoparticles and increase their electrophoretic mobility and zeta potential. This, together with a surfactant layer on the nanoparticles, shifts the slip plane towards the solid surface, meaning that the attraction energy between the nanoparticle and the cell necessary for adsorption-mediated uptake is enhanced [68]. The slightly negatively-charged to neutral zeta potential of the nanoparticles in this study may still be capable of cell penetration, which can outperform positively-charged species due to strong and non-specific interactions with the plasma membrane [69].

The contrast in an MR image is a function of the different signal intensities from the volume elements; the signal intensity is dependent on the water proton density and the longitudinal $\left(T_{1}\right)$ and transverse $\left(\mathrm{T}_{2}\right)$ relaxation times of the excited proton spins to the ground state; the relaxation times of protons in the target tissue are influenced by the presence of MR contrast agents that can be broadly classified as $\mathrm{T}_{1}$ or $\mathrm{T}_{2}$-contrast agents according its predominant effect on the relaxation times. SPIO is a type of $\mathrm{T}_{2}$-constrast agent that causes marked reductions in $\mathrm{T}_{2}$-relaxation time and signal intensity, and the results in our dose escalation phantom MR experiments of PBCA-SPIO NPs were comparable with those reported in the literature [70]. The nano-system-based iron oxide not only improves its dispersity and colloidal stability, but also increases the net magnetic moment to optimize the saturation magnetization, such that the $\mathrm{T}_{2}$-relaxitivity can be shortened for a greater $\mathrm{MR}$ contrast [71,72]. The inclusion of SPIO in our delivery system can potentially be used to study the fate of the nanoparticles or the nanoparticle-treated iPSCs by MR imaging; furthermore, the presence of SPIO in the nanoparticles could offer the option of targeted delivery by using an externally applied magnetic field across the site of interest [73].

Various in vitro differentiation protocols have been described for the derivation of neurons from iPSCs, which often require multiple inductive agents in a multi-step process that can take weeks to months [74-76]. The lengthy step in obtaining iPSCs by the reprogramming of somatic cells, followed by the protracted differentiation process associated with the possible need for embryoid body formation under undefined stromal co-culture systems, and the low yield of neurons with variable maturation stages and functional properties, limits the clinical utility of autogenic iPSC-derived cell products as a source of cell replacement therapy $[27,77,78]$. Dual inhibition of the SMAD pathway can be utilized to overcome these problems $[79,80]$, which relies on the synergistic action of Noggin, a bone morphogenetic inhibitor, and small molecule SB431542, an anaplastic lymphoma kinase inhibitor to block phosphorylation of SMAD-1, 5, 8 and SMAD-2, 3 of the respective pathways, and ultimately affect the downstream formation of SMAD complex in a way that the pattern of gene expression is driven towards neural differentiation [81]; greater than $80 \%$ differentiation efficiency by dual SMAD inhibition can be achieved within 19 days under adherent culture conditions [82]. Alternatively, the one-step forced expression of the master neural transcriptional regulator neurogenin- 2 by lentiviral transduction of iPSCs has been reported to produce a homogenous population of mature neurons within 2 to 3 weeks, with nearly 100\% differentiation efficiency of the transduced cells [83-85]. The envisioned "protein-plus cell" approach seeks to shorten the preparatory time window, and aims for the transplantation of cells at the earliest possible differentiation stage, followed by continual neutrophin stimulus through the ongoing administration of BDNF-containing nanoparticles to further assist in healing. Neurotrophins such as BDNF are the key regulators of cell fate and function in 
the nervous system [86]. We previously reported the forced expression of BDNF in iPSCs by the non-viral transduction of BDNF gene using a PBCA NP delivery system which resulted in neuron-like cells in as early as 7 days, and showed that activation of the phosphatidylinositol-3-OH kinase/Akt kinase pathway is capable of neural lineage specification [87]. In this study, BDNF-containing PBCA NPs were developed as an alternative to BDNF gene transduction; the use of these nanoparticles resulted in distinct cell populations distinguishable by immunofluorescence for neural markers and morphology in as early as 7 days consisting of large irregularly shaped neural stem/progenitor cells, small neuron-like cells, and compact rounded cells resembling undifferentiated iPSCs, as would be expected during the early days of the differentiation process. This was in agreement with the flow cytometric analysis, showing only slightly greater than $40 \%$ of cells bearing beta III tubulin. Although the treated cells showed evidence of neural differentiation, the morphologic differences, with respect to axonal and dendritic growth and intercellular connections, were much more extensive in those treated with surface-adsorbed BDNF. This is consistent with the fact that BDNF acts on the extracellular domain of the tropmycin kinase $B$ receptor located in the cell membrane [88]; therefore, the ease of BDNF release into the extracellular compartment before the nanoparticles are taken up for cell tracking will optimize the ligand-receptor interaction to activate downstream pathways. Treatment with an equivalent concentration of free BDNF did not result in appreciable neural differentiation; this was likely caused by the rapid degradation of BDNF in vitro without the protection of the delivery system [54]. The elevated levels of BDNF expression seen in iPSCs treated with the BDNF-containing nanoparticles has been described as a self-amplifying, positive-feedback autocrine mechanism during neural development to ensure an adequate level of BDNF activity necessary for neural differentiation and growth [89]. The one-time administration and limited half-life of free BDNF in vitro may explain the lack of findings for the cells treated with BDNF alone.

Even though the adsorption system worked well in vitro, it may be less suitable for delivery in vivo owing to the expected burst release profile and the short half-life of BDNF in plasma; thus, the encapsulation system may have the advantage of preventing losses during its transit to the target [90].

We have demonstrated a multiplexed PBCA NP delivery system for BDNF and SPIO with the potential for simultaneous induction of neural differentiation and tracking capability of the treated iPSCs. T80 coating, even at minute concentrations of $0.01 \%(w / v)$ allowed for increased permeability of the delivery system across the in vitro contact co-culture BBB model made up of RBMECs and CTX TNA2. Neural differentiation appeared best with those containing the adsorbed BDNF, consistent with its site of interaction at the extracellular domain of the tropmycin kinase $B$ receptor, and the derivation process may be as short as 7 days. However, the $40 \%$ differentiation efficiency by the one-time administration of BDNF-containing PBCA NPs over free BDNF on the neural differentiation of mouse iPSCs is far from perfect, and many questions and challenges lie ahead before the "protein-plus-cell" approach can be realized; these include the possible differences in inductiveness on different clones of iPSCs, and, more importantly, on things such as human iPSCs, the fate of the treated iPSCs on a longer time scale, the effect of repeated exposure to the BDNF-bearing nanoparticles, the requirement of additional extrinsic factors other than BDNF for functional maturation and derivation of neural subtypes, better characterization of the treated cells by methods such as transcriptome analysis, and ultimately, the relevance of such findings to in vivo disease models.

\section{Materials and Methods}

\subsection{Mouse iPSCs}

Mouse iPSCs were purchased from System Biosciences (Mountain View, CA, USA). The iPSCs were maintained in ESGRO complete PLUS clonal grade medium (Millipore, Billerica, MA, USA). When the culture reached $80-90 \%$ confluence, the cells were passaged at a ratio of 1:4 in $75 \mathrm{~cm}^{2}$ tissue culture flasks pre-coated with $0.1 \%$ gelatin. Cells of passages $14-18$ were used for all the experiments. 


\subsection{Synthesis of SPIO}

For the synthesis of SPIO particles, $1.83 \mathrm{~g} \mathrm{FeCl}{ }_{3} \cdot 6 \mathrm{H}_{2} \mathrm{O}$ and $\mathrm{FeCl}_{2} \cdot 6 \mathrm{H}_{2} \mathrm{O}$ were dissolved in $25 \mathrm{~mL}$ of deionized water. The solution was stirred rigorously for $5 \mathrm{~min}$ at room temperature after the slow addition of $4 \mathrm{~mL} 25 \%$ ammonia aqueous solution. The formation of iron oxide was indicated by the solution's change in color from brown to black. The precipitant was isolated by a permanent magnet, which was then re-dispersed and washed with deionized water. This procedure was repeated three times to purify the synthesized iron oxide particles. Finally, the SPIO was stored in $40 \mathrm{~mL}$ of deionized water for further experimentation.

\subsection{Fabrication of PBCA-BDNF-SPIO NP (BDNF Encapsulation System) and BDNF-PBCA-SPIO NP (BDNF Adsorption System) with and without T80 Coating}

PBCA NPs entrapping SPIO and BDNF were prepared by the emulsion polymerization technique; the fabrication method was reported previously with minor modifications [53,91]. Briefly, the PBCA NPs entrapping SPIO were made by adding $1 \%(v / v)$ BCA (Sicomet, Sichel Werk, Hanover, Germany) into a $0.01 \mathrm{~N} \mathrm{HCl}$ acidic polymerization medium containing 1\% $(w / v)$ dextran 70,000 (Fluka Biochemika, Buchs, Switzerland) and $0.002 \%(w / v)$ SPIO; the solution was kept at $25{ }^{\circ} \mathrm{C}$ and stirred at $400 \mathrm{rpm}$ for $3 \mathrm{~h}$. Polymerization was terminated by neutralization with $0.1 \mathrm{~N} \mathrm{NaOH}$; the suspension was filtrated through a $1 \mu \mathrm{m}$ filter paper to remove the larger polymer aggregates. $200 \mathrm{ng} / \mathrm{mL}$ BDNF (R\&D Systems, Minneapolis, MN, USA) was included in the initial polymerization medium for the encapsulating system of BDNF, whereas the same amount of BDNF was added to the suspension of formed PBCA-SPIO NPs and stirred for $1 \mathrm{~h}$ at $400 \mathrm{rpm}$ for the adsorption system of BDNF. For the T80-coated formulation of the respective systems, the nanoparticles were further incubated in $0.01 \%$ $(w / v)$ of T80 and stirred for another $30 \mathrm{~min}$. The excess unloaded agents in each preparation were removed by ultrafiltration (Amicon Ultra-4 30K devices, Millipore, Billerica, MA, USA).

FITC labeling of the nanoparticles was achieved by replacing dextran 70000 with FITC-dextran (Fluka Biochemika, Buchs, Switzerland) in the reaction system. Sterilization of the nanoparticle formulation was achieved by filtering through a $0.22 \mu \mathrm{m}$ filtration unit (Millipore).

\subsection{Characterization of Nanoparticles}

The particle size and zeta potential of the nanoparticles were determined by the Zetasizer Nano ZS90 (Malvern, Worcestershire, UK) with photo correlation spectroscopy. The nanoparticle morphology was obtained by a FE-SEM (S-5000, Hitachi, Tokyo, Japan), and by a TEM (H-7500, Hitachi) after negative staining with $2 \%(w / v)$ phosphotungstic acid (Sigma, St. Louis, MO, USA) for a strong contrast in the images.

\subsection{Loading Efficiency of BDNF and SPIO}

The free BDNF in solution was analyzed with a human BDNF enzyme linked immunosorbent assay (ELISA) kit (R\&D Systems) after ultrafiltration. The absorbance was measured by a spectrophotometer (ELISA reader) set to a wavelength of $450 \mathrm{~nm}$. The LE of BDNF by the nanoparticles is given by the formula: $L E_{\mathrm{BDNF}}(\%)=$ (total weight of $\mathrm{BDNF}-$ weight of BDNF in supernatant $) /$ total weight of BDNF $\times 100$.

The LE of SPIO was obtained by thermogravimetric analysis using a Mettler TGA/SDTA 851 (Mettler Toledo, Columbus, OH, USA) after freeze-drying.

\subsection{Cytotoxicity Assay}

The cytotoxicity of the nanoparticles to RBMECs, CTX TNA2, and iPSCs was estimated by the XTT cell viability assay (Cell Proliferation kit, Biological Industries, Beit Haemek, Israel). Cells were seeded onto a 96-well plate at a density of 5000 cells/well and incubated overnight. The cells were then treated with different concentrations of nanoparticles in $100 \mu \mathrm{L}$ growth medium and incubated for $2 \mathrm{~h}$, 
after which the tetrazolium dye for the XTT assay was added and incubated for $24 \mathrm{~h}$. The reduced derivative of the tetrazolium dye was read by the EnSpire Multimode Plate Reader (Perkin Elmer Inc., Waltham, MA, USA) with the absorbance wavelength set at $490 \mathrm{~nm}$.

\subsection{Immunofluorescence Staining and Flow Cytometry Analysis}

The iPSCs were seeded at a density of $1 \times 10^{5} \mathrm{cells} / \mathrm{cm}^{2}$ on a $0.1 \%$ gelatin-coated culture dish and cultured with ESGRO complete PLUS clonal grade medium in a humidified $5 \% \mathrm{CO}_{2}$ incubator at $37{ }^{\circ} \mathrm{C}$ overnight. The iPSCs were cultured with $125 \mathrm{pg} / \mathrm{mL}$ of free BDNF or $25 \mu \mathrm{g} / \mathrm{mL}$ of PBCA-SPIO NPs with and without BDNF for 7 days; the concentration of the free BDNF was taken as the equivalent of $25 \mu \mathrm{g} / \mathrm{mL}$ of BDNF-containing nanoparticles, assuming 100\% loading and release efficiency. The cells were fixed with $4 \%$ formaldehyde for $10 \mathrm{~min}$ and stained with the primary antibody against BDNF (1:1000, Abcam, Cambridge, MA, USA), beta III tubulin (1:200, Abcam), NF H (1:200, Abcam), and Nestin (1:200, Abcam) at $4{ }^{\circ} \mathrm{C}$ overnight, and detected with an Alexa Fluor ${ }^{\circledR} 488$ (1:1000, Abcam)-conjugated or Alexa Fluor ${ }^{\circledR} 594$ (1:1000, Abcam)-conjugated secondary antibody at room temperature for $1 \mathrm{~h}$. The nuclei of iPSCs were counterstained with 4', 6-diamidino-2-phenylindole (DAPI). The images were captured by a confocal laser-scanning microscope (Leica TCS SP5 II, Wetzlar, Germany). The fluorescence intensity of BDNF was quantified by imageJ analysis, normalized to the fluorescence intensity of DAPI.

Flow cytometry was used to calculate the percentage of iPSCs differentiating into neurons for each of the respective treatment groups at Day 7 . The cells were fixed with $4 \%$ formaldehyde for 10 min and treated with $0.1 \%(v / v)$ Triton X-100 in DPBS for $10 \mathrm{~min}$. After washing with DPBS, the cells were reacted with rabbit polyclonal anti-beta III tubulin (1:100, Abcam) at $4{ }^{\circ} \mathrm{C}$ for $1 \mathrm{~h}$, and goat polyclonal secondary antibody to rabbit IgG-H\&L Alexa Flour ${ }^{\circledR} 488$ conjugate $\left(1: 4000\right.$, Abcam) at $4{ }^{\circ} \mathrm{C}$ for $30 \mathrm{~min}$. Then, the fluorescence-labelled cells were stabilized by suspension in $200 \mathrm{~L}$ DPBS with $1 \%$ $(v / v)$ formaldehyde at $4{ }^{\circ} \mathrm{C}$. Processed single-cell suspensions were detected by a BD FACSCanto ${ }^{\mathrm{TM}}$ II flow cytometer (BD Biosciences, California, CA, USA) and analyzed by Cell Quest software (BD Biosciences).

4.7.1. In Vitro BBB Model by Co-Culturing Endothelial Cells (Upper Chamber) and Astrocytes (Opposite the Upper Chamber)

The isolation of RBMECs and the cultivation of RBMECs and CTX TNA2 were described previously [92]. The top and bottom surfaces of a sterilized polyethylene terephthalate (PET) membrane (cell culture insert, pore size $1.0 \mu \mathrm{m}, \mathrm{BD}$, Franklin Lakes, NJ, USA) were coated with human fibronectin (Sigma), and $1 \times 10^{5}$ cells $/ \mathrm{cm}^{2}$ of CTX TNA2 (Bioresource Collection and Research Center; no. 60547, Hsin-Chu, Taiwan) were seeded on the bottom surface of the PET membrane in an inverted transwell system, and cultivated in the $\mathrm{CO}_{2}$ incubator for $30 \mathrm{~min}$; then, $1 \times 10^{5}$ cells $/ \mathrm{cm}^{2}$ of RBMECs were seeded on the top surface of the PET membrane. The resultant transwell system of RBMECs/CTX TNA2 was placed in a 24-well micro-titer plate (BD Biosciences) and co-cultivated in the $\mathrm{CO}_{2}$ incubator over 10 days to form a confluent monolayer of RBMECs regulated by CTX TNA2. The lower (outer) chamber was filled with the Dulbecco's Modified Eagle Medium (DMEM) (Gibco, Grand Island, NY, USA) with $10 \%$ fetal bovine serum (FBS) (Hyclone, Logan, UT, USA) for CTX TNA2. The medium in the upper (inner) chamber was the endothelial cell medium (ECM, ScienCell, Corte Del Cedro Carlsbad, CA, USA) containing $1 \%$ endothelial cell growth supplement, $10 \%$ FBS, and $1 \%$ penicillin/streptomycin solution. Both media were replaced every 2 days and maintained at the same height to reduce the effect of hydrostatic pressure on RBMECs and CTX TNA2.

\subsubsection{TEER of RBMECs/CTX TNA2 Monolayer after Treatment with the Nanoparticles}

The donor and receiver chambers of the transwell system faced the RBMECs and CTX TNA2, respectively. A nanoparticle concentration of $25 \mu \mathrm{g} / \mathrm{mL}$ in the ECM was added to the donor chamber and cultured in the humidified $\mathrm{CO}_{2}$ incubator at $37^{\circ} \mathrm{C}$ for $4 \mathrm{~h}$. The donor and receiver chambers were 
filled with the respective culture media to the same height. A Millicell voltohmmeter (Millipore) was applied to determine the TEER of the PET insert with and without the RBMECs/CTX TNA2.

\subsubsection{Permeability Across Co-Cultured RBMECs/CTX TNA2 System}

The transwell system containing the RBMECs/CTX TNA2 was used to determine the permeability coefficient of FITC-labeled nanoparticles across the CTX TNA2-regulated monolayer of RBMECs $\left(P_{\text {RBMECs } / \text { CTX TNA2 }}\right)$. The donor chamber was given $25 \mu \mathrm{g} / \mathrm{mL}$ of nanoparticles and placed in the humidified $\mathrm{CO}_{2}$ incubator. After $4 \mathrm{~h}$, the concentration of FITC-labeled nanoparticles in the receiver chamber was analyzed by the EnSpire Multimode Plate Reader, set at the emission and excitation wavelengths of $525 \mathrm{~nm}$ and $488 \mathrm{~nm}$, respectively. The medium in the receiver chamber

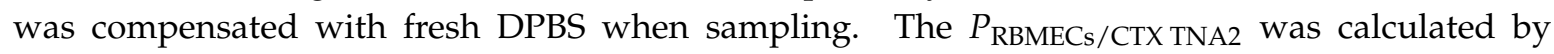
$1 / P_{\text {RBMECs } / \text { CTX TNA2 }}=1 / P_{\mathrm{e}}-1 / P_{\mathrm{m}}$, where $P_{\mathrm{e}}$ and $P_{\mathrm{m}}$ represent the permeability of FITC-labeled nanoparticles across the PET membrane containing RBMECs/CTX TNA2 and the permeability of the same nanoparticles across the cell-free PET membrane, respectively.

\subsection{Prussian Blue Staining for Detection of SPIOs}

The iPSCs were seeded at a density of $1 \times 10^{5}$ cells $/ \mathrm{cm}^{2}$ on a $0.1 \%$ gelatin-coated culture dish and cultured with ESGRO complete PLUS clonal grade medium in a humidified $5 \% \mathrm{CO}_{2}$ incubator at $37^{\circ} \mathrm{C}$ overnight. The iPSCs was treated with $25 \mu \mathrm{g} / \mathrm{mL}$ PBCA-SPIO NPs for $4 \mathrm{~h}$, then fixed with $4 \%$ formaldehyde and washed with $1 \times$ PBS; these were further incubated with a 1:1 mixture of $4 \%$ potassium ferrocyanide and $4 \%$ hydrochloride acid for $30 \mathrm{~min}$. The cells were observed under a light microscope (Zeiss Axio Observer, Oberkochen, Germany).

\subsection{In Vitro MRI Signal Intensity of the Nanoparticles}

MR tests using PBCA-SPIO NPs were performed to assess the efficacy of the probe as a T2-weighted MR imaging contrast agent. PBCA-SPIO NPs of various concentrations $(1,5,25,50$, 100 , and $200 \mu \mathrm{g} / \mathrm{mL}$ ) were suspended in $1.5 \mathrm{~mL}$ eppendorfs containing phosphate buffer saline solution. The tubes were embedded in a homemade tank filled with $1 \%$ agarose gel. The tank with one eppendorf was inserted into the MR coil with the long axis of the vials parallel to the static magnetic field. T2-weighted MR images were acquired on a Burker 7.0-T small animal MR imaging system (ClinScan, Bruker, Billerica, MA, USA) with a fast spin echo sequence under the following parameters: $\mathrm{TR}=4000 \mathrm{~ms} ; \mathrm{TE}=109 \mathrm{~ms}$ with 16 echo-train length.

\subsection{Statistical Analysis}

The numeric variables were expressed as mean \pm standard deviation. All statistical analyses were performed with the GraphPad Prism ${ }^{\circledR} 5$ software (La Jolla, CA, USA). The data were analyzed with the one-way analysis of variance (ANOVA) and Bonferroni post-hoc test. A $p$ value of 0.05 or less was thought to indicate a significant statistical difference.

\section{Conclusions}

Neural differentiation from iPSCs can be induced by the administration of BDNF carried by PBCA NPs, and the multiplexing capabilities of this polymeric delivery platform allows for further modification, such as the inclusion of SPIO for added MR tracking functionality and T80 coating for enhanced penetration through the BBB. Treatment of iPSCs with surface-adsorbed BDNF nanoparticles was found to give rise to cells with better axonal and dendrite growth and intercellular connectivity, which was noticeable in as early as 7 days, compared to the encapsulated formulation.

Author Contributions: C.-Y.C., M.-H.L. and J.-T.Y. conceived and designed the experiments; C.-Y.C., I.-N.L. and J.-C.Y. performed the experiments; T.-H.L. analyzed the data; C.-Y.C. contributed reagents/materials/anaylsis tools; and M.H.-C.L. wrote the manuscript. K.-T.C., W.-C.H. proofread the manuscript. 
Funding: This research was funded by the Ministry of Science and Technology R.O.C. grant number: NSC 102-2314-B-182A-071, MOST 103-2314-B-182A-097 and MOST 104-2314-B-182A-037, and Chang Gung Memorial Hospital, Chiayi grant number: CMRPG6G0491, CMRPG6H0501, CORPG6G0181, CORPG6D0081-3, BMRP492 and CMRPG6D0301-3. The APC was funded by the Chang Gung Memorial Hospital Chiayi.

Acknowledgments: We would like to acknowledge Shyh-Liang Lou (Department of Biomedical Engineering and Nanotechnology, Chung Yuan Christian University, Taoyuan, Taiwan) for assisting TGA. We appreciate the Chang Gung Memorial Hospital Microscope Core Laboratory in Linkou for assisting SEM and TEM. We also would like to acknowledge the Leica SP5II confocal microscope service provided by the Expensive Advanced Instrument Core Laboratory, Department of Medical Research and Development, Chang Gung Memorial Hospital at Chiayi.

Conflicts of Interest: The authors declare no conflict of interest.

\section{References}

1. Mimeault, M.; Batra, S.K. Great promise of tissue-resident adult stem/progenitor cells in transplantation and cancer therapies. Adv. Exp. Med. Biol. 2012, 741, 171-186. [CrossRef] [PubMed]

2. Bifari, F.; Berton, V.; Pino, A.; Kusalo, M.; Malpeli, G.; Di Chio, M.; Bersan, E.; Amato, E.; Scarpa, A.; Krampera, M.; et al. Meninges harbor cells expressing neural precursor markers during development and adulthood. Front. Cell. Neurosci. 2015, 9, 383. [CrossRef]

3. Fiorelli, R.; Cebrian-Silla, A.; Garcia-Verdugo, J.M.; Raineteau, O. The adult spinal cord harbors a population of GFAP-positive progenitors with limited self-renewal potential. GLIA 2013, 61, 2100-2113. [CrossRef] [PubMed]

4. Palmer, T.D.; Takahashi, J.; Gage, F.H. The adult rat hippocampus contains primordial neural stem cells. Mol. Cell. Neurosci. 1996, 8, 389-404. [CrossRef] [PubMed]

5. Gritti, A.; Bonfanti, L.; Doetsch, F.; Caille, I.; Alvarez-Buylla, A.; Lim, D.A.; Galli, R.; Verdugo, J.M.G.; Herrera, D.G.; Vescovi, A.L. Multipotent neural stem cells reside into the rostral extension and olfactory bulb of adult rodents. J. Neurosci. 2002, 22, 437-445. [CrossRef] [PubMed]

6. Nunes, M.C.; Roy, N.S.; Keyoung, H.M.; Goodman, R.R.; McKhann, G., 2nd; Jiang, L.; Kang, J.; Nedergaard, M.; Goldman, S.A. Identification and isolation of multipotential neural progenitor cells from the subcortical white matter of the adult human brain. Nat. Med. 2003, 9, 439-447. [CrossRef] [PubMed]

7. Steward, M.M.; Sridhar, A.; Meyer, J.S. Neural regeneration. Curr. Top. Microbiol. Immunol. 2013, 367, $163-191$. [CrossRef] [PubMed]

8. Rolls, A.; Shechter, R.; Schwartz, M. The bright side of the glial scar in CNS repair. Nat. Rev. Neurosci. 2009, 10, 235-241. [CrossRef]

9. Anderson, M.A.; Burda, J.E.; Ren, Y.; Ao, Y.; O’Shea, T.M.; Kawaguchi, R.; Coppola, G.; Khakh, B.S.; Deming, T.J.; Sofroniew, M.V. Astrocyte scar formation aids central nervous system axon regeneration. Nature 2016, 532, 195. [CrossRef] [PubMed]

10. Sohur, U.S.; Emsley, J.G.; Mitchell, B.D.; Macklis, J.D. Adult neurogenesis and cellular brain repair with neural progenitors, precursors and stem cells. Philos. Trans. R. Soc. Lond. Ser. B Biol. Sci. 2006, 361, 1477-1497. [CrossRef]

11. Ekdahl, C.T.; Claasen, J.H.; Bonde, S.; Kokaia, Z.; Lindvall, O. Inflammation is detrimental for neurogenesis in adult brain. Proc. Natl. Acad. Sci. USA 2003, 100, 13632-13637. [CrossRef] [PubMed]

12. Encinas, J.M.; Michurina, T.V.; Peunova, N.; Park, J.H.; Tordo, J.; Peterson, D.A.; Fishell, G.; Koulakov, A.; Enikolopov, G. Division-coupled astrocytic differentiation and age-related depletion of neural stem cells in the adult hippocampus. Cell Stem Cell 2011, 8, 566-579. [CrossRef] [PubMed]

13. Bernal, G.M.; Peterson, D.A. Phenotypic and gene expression modification with normal brain aging in GFAP-positive astrocytes and neural stem cells. Aging Cell 2011, 10, 466-482. [CrossRef] [PubMed]

14. Drago, D.; Basso, V.; Gaude, E.; Volpe, G.; Peruzzotti-Jametti, L.; Bachi, A.; Musco, G.; Andolfo, A.; Frezza, C.; Mondino, A.; et al. Metabolic determinants of the immune modulatory function of neural stem cells. J. Neuroinflamm. 2016, 13, 232. [CrossRef] [PubMed]

15. Ravanidis, S.; Poulatsidou, K.N.; Lagoudaki, R.; Touloumi, O.; Polyzoidou, E.; Lourbopoulos, A.; Nousiopoulou, E.; Theotokis, P.; Kesidou, E.; Tsalikakis, D.; et al. Subcutaneous transplantation of neural precursor cells in experimental autoimmune encephalomyelitis reduces chemotactic signals in the central nervous system. Stem Cells Transl. Med. 2015, 4, 1450-1462. [CrossRef] [PubMed] 
16. Wang, Z.; Cui, C.; Li, Q.; Zhou, S.; Fu, J.; Wang, X.; Zhuge, Q. Intracerebral transplantation of foetal neural stem cells improves brain dysfunction induced by intracerebral haemorrhage stroke in mice. J. Cell. Mol. Med. 2011, 15, 2624-2633. [CrossRef] [PubMed]

17. Takahashi, K.; Yamanaka, S. Induction of Pluripotent Stem Cells from Mouse Embryonic and Adult Fibroblast Cultures by Defined Factors. Cell 2006, 126, 663-676. [CrossRef]

18. Takahashi, K.; Yamanaka, S. Induced pluripotent stem cells in medicine and biology. Development 2013, 140, 2457-2461. [CrossRef]

19. Rong, Z.; Wang, M.; Hu, Z.; Stradner, M.; Zhu, S.; Kong, H.; Yi, H.; Goldrath, A.; Yang, Y.-G.; Xu, Y.; et al. An effective approach to prevent immune rejection of human ESC-derived allografts. Cell Stem Cell 2014, 14, 121-130. [CrossRef]

20. Zhang, G.; Shang, B.; Yang, P.; Cao, Z.; Pan, Y.; Zhou, Q. Induced pluripotent stem cell consensus genes: Implication for the risk of tumorigenesis and cancers in induced pluripotent stem cell therapy. Stem Cells Dev. 2012, 21, 955-964. [CrossRef]

21. Yamashita, T.; Kawai, H.; Tian, F.; Ohta, Y.; Abe, K. Tumorigenic development of induced pluripotent stem cells in ischemic mouse brain. Cell Transpl. 2011, 20, 883-891. [CrossRef] [PubMed]

22. Liang, Y.; Zhang, H.; Feng, Q.-S.; Cai, M.-B.; Deng, W.; Qin, D.; Yun, J.-P.; Tsao, G.S.W.; Kang, T.; Esteban, M.A.; et al. The propensity for tumorigenesis in human induced pluripotent stem cells is related with genomic instability. Chin. J. Cancer 2013, 32, 205-212. [CrossRef]

23. Tateno, H.; Onuma, Y.; Ito, Y.; Minoshima, F.; Saito, S.; Shimizu, M.; Aiki, Y.; Asashima, M.; Hirabayashi, J. Elimination of tumorigenic human pluripotent stem cells by a recombinant lectin-toxin fusion protein. Stem Cell Rep. 2015, 4, 811-820. [CrossRef] [PubMed]

24. Seki, T.; Fukuda, K. Methods of induced pluripotent stem cells for clinical application. World J. Stem Cells 2015, 7, 116-125. [CrossRef] [PubMed]

25. El Khatib, M.M.; Ohmine, S.; Jacobus, E.J.; Tonne, J.M.; Morsy, S.G.; Holditch, S.J.; Schreiber, C.A.; Uetsuka, K.; Fusaki, N.; Wigle, D.A.; et al. Tumor-Free Transplantation of Patient-Derived Induced Pluripotent Stem Cell Progeny for Customized Islet Regeneration. Stem Cells Transl. Med. 2016, 5, 694-702. [CrossRef] [PubMed]

26. Ebert, A.D.; Yu, J.; Rose, F.F.; Mattis, V.B.; Lorson, C.L.; Thomson, J.A.; Svendsen, C.N. Induced pluripotent stem cells from a spinal muscular atrophy patient. Nature 2009, 457, 277-280. [CrossRef] [PubMed]

27. Hu, B.Y.; Weick, J.P.; Yu, J.; Ma, L.X.; Zhang, X.Q.; Thomson, J.A.; Zhang, S.C. Neural differentiation of human induced pluripotent stem cells follows developmental principles but with variable potency. Proc. Natl. Acad. Sci. USA 2010, 107, 4335-4340. [CrossRef]

28. Lim, J.Y.; Park, S.I.; Oh, J.H.; Kim, S.M.; Jeong, C.H.; Jun, J.A.; Lee, K.S.; Oh, W.; Lee, J.K.; Jeun, S.S. Brain-derived neurotrophic factor stimulates the neural differentiation of human umbilical cord blood-derived mesenchymal stem cells and survival of differentiated cells through MAPK/ERK and PI3K/Akt-dependent signaling pathways. J. Neurosci. Res. 2008, 86, 2168-2178. [CrossRef]

29. Bolton, M.M.; Pittman, A.J.; Lo, D.C. Brain-derived neurotrophic factor differentially regulates excitatory and inhibitory synaptic transmission in hippocampal cultures. J. Neurosci. 2000, 20, 3221-3232. [CrossRef]

30. Zheng, J.; Sun, J.; Lu, X.; Zhao, P.; Li, K.; Li, L. BDNF promotes the axonal regrowth after sciatic nerve crush through intrinsic neuronal capability upregulation and distal portion protection. Neurosci. Lett. 2016, 621, 1-8. [CrossRef]

31. Ramge, P.; Unger, R.E.; Oltrogge, J.B.; Zenker, D.; Begley, D.; Kreuter, J.; Von Briesen, H. Polysorbate-80 coating enhances uptake of polybutylcyanoacrylate (PBCA)-nanoparticles by human and bovine primary brain capillary endothelial cells. Eur. J. Neurosci. 2000, 12, 1931-1940. [CrossRef] [PubMed]

32. Koffie, R.M.; Farrar, C.T.; Saidi, L.-J.; William, C.M.; Hyman, B.T.; Spires-Jones, T.L. Nanoparticles enhance brain delivery of blood-brain barrier-impermeable probes for in vivo optical and magnetic resonance imaging. Proc. Natl. Acad. Sci. USA 2011, 108, 18837-18842. [CrossRef] [PubMed]

33. Duan, J.; Zhang, Y.; Chen, W.; Shen, C.; Liao, M.; Pan, Y.; Wang, J.; Deng, X.; Zhao, J. Cationic polybutyl cyanoacrylate nanoparticles for DNA delivery. J. Biomed. Biotechnol. 2009, 2009, 149254. [CrossRef] [PubMed]

34. Kurakhmaeva, K.B.; Djindjikhashvili, I.A.; Petrov, V.E.; Balabanyan, V.U.; Voronina, T.A.; Trofimov, S.S.; Kreuter, J.; Gelperina, S.; Begley, D.; Alyautdin, R.N. Brain targeting of nerve growth factor using poly(butyl cyanoacrylate) nanoparticles. J. Drug Target. 2009, 17, 564-574. [CrossRef] [PubMed] 
35. Xu, Z.R.; Wang, W.F.; Liang, X.F.; Liu, Z.H.; Liu, Y.; Lin, L.; Zhu, X. Protective Effects of Poly (butyl) Cyanoacrylate Nanoparticles Containing Vasoactive Intestinal Peptide Against 6-Hydroxydopamine-Induced Neurotoxicity In Vitro. J. Mol. Neurosci. 2015, 55, 854-864. [CrossRef]

36. Tian, X.-H.; Lin, X.-N.; Wei, F.; Feng, W.; Huang, Z.-C.; Wang, P.; Ren, L.; Diao, Y. Enhanced brain targeting of temozolomide in polysorbate-80 coated polybutylcyanoacrylate nanoparticles. Int. J. Nanomed. 2011, 6, 445-452. [CrossRef]

37. Gao, S.; Xu, Y.; Asghar, S.; Chen, M.; Zou, L.; Eltayeb, S.; Huo, M.; Ping, Q.; Xiao, Y. Polybutylcyanoacrylate nanocarriers as promising targeted drug delivery systems. J. Drug Target. 2015, 23, 481-496. [CrossRef]

38. Cabeza, L.; Ortiz, R.; Arias, J.L.; Prados, J.; Ruiz Martinez, M.A.; Entrena, J.M.; Luque, R.; Melguizo, C. Enhanced antitumor activity of doxorubicin in breast cancer through the use of poly(butylcyanoacrylate) nanoparticles. Int. J. Nanomed. 2015, 10, 1291-1306. [CrossRef]

39. Melguizo, C.; Cabeza, L.; Prados, J.; Ortiz, R.; Caba, O.; Rama, A.R.; Delgado, Á.V.; Arias, J.L. Enhanced antitumoral activity of doxorubicin against lung cancer cells using biodegradable poly(Butylcyanoacrylate) nanoparticles. Drug Des. Dev. Therapy 2015, 9, 6433-6444. [CrossRef]

40. Kolter, M.; Ott, M.; Hauer, C.; Reimold, I.; Fricker, G. Nanotoxicity of poly(n-butylcyano-acrylate) nanoparticles at the blood-brain barrier, in human whole blood and in vivo. J. Controll. Release 2015, 197, 165-179. [CrossRef]

41. Kreuter, J.; Alyautdin, R.N.; Kharkevich, D.A.; Ivanov, A.A. Passage of peptides through the blood-brain barrier with colloidal polymer particles (nanoparticles). Brain Res. 1995, 674, 171-174. [CrossRef]

42. Li, Y.J.; Barthes-Biesel, D.; Salsac, A.V. Polymerization kinetics of n-butyl cyanoacrylate glues used for vascular embolization. J. Mech. Behav. Biomed. Mater. 2017, 69, 307-317. [CrossRef] [PubMed]

43. Kakaei, F.; Seyyed Sadeghi, M.S.; Sanei, B.; Hashemzadeh, S.; Habibzadeh, A. A randomized clinical trial comparing the effect of different haemostatic agents for haemostasis of the liver after hepatic resection. HPB Surg. 2013, 2013, 587608. [CrossRef] [PubMed]

44. Bozkurt, M.K.; Saydam, L. The use of cyanoacrylates for wound closure in head and neck surgery. Eur. Arch. Oto-Rhino-Laryngol. 2008, 265, 331-335. [CrossRef] [PubMed]

45. Tamatani, S.; Koike, T.; Ito, Y.; Tanaka, R. Embolization of Arteriovenous Malformation with Diluted Mixture of NBCA. Int. Neuroradiol. 2000, 6, 187-190. [CrossRef]

46. Sulheim, E.; Baghirov, H.; von Haartman, E.; Boe, A.; Aslund, A.K.; Morch, Y.; Davies Cde, L. Cellular uptake and intracellular degradation of poly(alkyl cyanoacrylate) nanoparticles. J. Nanobiotechnol. 2016, 14, 1. [CrossRef] [PubMed]

47. O'Sullivan, C.; Birkinshaw, C. Hydrolysis of poly (n-butylcyanoacrylate) nanoparticles using esterase. Polym. Degrad. Stab. 2002, 78, 7-15. [CrossRef]

48. Chaudhari, K.R.; Ukawala, M.; Manjappa, A.S.; Kumar, A.; Mundada, P.K.; Mishra, A.K.; Mathur, R.; Monkkonen, J.; Murthy, R.S. Opsonization, biodistribution, cellular uptake and apoptosis study of PEGylated PBCA nanoparticle as potential drug delivery carrier. Pharm. Res. 2012, 29, 53-68. [CrossRef]

49. Wilson, B.; Samanta, M.K.; Santhi, K.; Kumar, K.P.; Paramakrishnan, N.; Suresh, B. Poly(n-butylcyanoacrylate) nanoparticles coated with polysorbate 80 for the targeted delivery of rivastigmine into the brain to treat Alzheimer's disease. Brain Res. 2008, 1200, 159-168. [CrossRef]

50. Ballabh, P.; Braun, A.; Nedergaard, M. The blood-brain barrier: An overview: Structure, regulation, and clinical implications. Neurobiol. Dis. 2004, 16, 1-13. [CrossRef]

51. Pulicherla, K.K.; Verma, M.K. Targeting Therapeutics Across the Blood Brain Barrier (BBB), Prerequisite Towards Thrombolytic Therapy for Cerebrovascular Disorders-An Overview and Advancements. AAPS PharmSciTech 2015, 16, 223-233. [CrossRef] [PubMed]

52. Helms, H.C.; Abbott, N.J.; Burek, M.; Cecchelli, R.; Couraud, P.O.; Deli, M.A.; Forster, C.; Galla, H.J.; Romero, I.A.; Shusta, E.V.; et al. In vitro models of the blood-brain barrier: An overview of commonly used brain endothelial cell culture models and guidelines for their use. J. Cereb. Blood Flow Metab. 2016, 36, 862-890. [CrossRef] [PubMed]

53. Wang, C.X.; Huang, L.S.; Hou, L.B.; Jiang, L.; Yan, Z.T.; Wang, Y.L.; Chen, Z.L. Antitumor effects of polysorbate-80 coated gemcitabine polybutylcyanoacrylate nanoparticles in vitro and its pharmacodynamics in vivo on C6 glioma cells of a brain tumor model. Brain Res. 2009, 1261, 91-99. [CrossRef] [PubMed] 
54. Bagad, M.; Khan, Z.A. Poly(n-butylcyanoacrylate) nanoparticles for oral delivery of quercetin: Preparation, characterization, and pharmacokinetics and biodistribution studies in Wistar rats. Int. J. Nanomed. 2015, 10, 3921-3935. [CrossRef]

55. Reimold, I.; Domke, D.; Bender, J.; Seyfried, C.A.; Radunz, H.E.; Fricker, G. Delivery of nanoparticles to the brain detected by fluorescence microscopy. Eur. J. Pharm. Biopharm. 2008, 70, 627-632. [CrossRef] [PubMed]

56. Mulik, R.S.; Monkkonen, J.; Juvonen, R.O.; Mahadik, K.R.; Paradkar, A.R. ApoE3 mediated poly(butyl) cyanoacrylate nanoparticles containing curcumin: Study of enhanced activity of curcumin against beta amyloid induced cytotoxicity using in vitro cell culture model. Mol. Pharm. 2010, 7, 815-825. [CrossRef] [PubMed]

57. Arechabala, B.; Coiffard, C.; Rivalland, P.; Coiffard, L.J.; de Roeck-Holtzhauer, Y. Comparison of cytotoxicity of various surfactants tested on normal human fibroblast cultures using the neutral red test, MTT assay and LDH release. J. Appl. Toxicol. 1999, 19, 163-165. [CrossRef]

58. Perriere, N.; Yousif, S.; Cazaubon, S.; Chaverot, N.; Bourasset, F.; Cisternino, S.; Decleves, X.; Hori, S.; Terasaki, T.; Deli, M.; et al. A functional in vitro model of rat blood-brain barrier for molecular analysis of efflux transporters. Brain Res. 2007, 1150, 1-13. [CrossRef]

59. Molino, Y.; Jabes, F.; Lacassagne, E.; Gaudin, N.; Khrestchatisky, M. Setting-up an in vitro model of rat blood-brain barrier (BBB): A focus on BBB impermeability and receptor-mediated transport. J. Vis. Exp. 2014, 28, e51278. [CrossRef]

60. Reichel, A.; Begley, D.J.; Abbott, N.J. An overview of in vitro techniques for blood-brain barrier studies. Methods Mol. Med. 2003, 89, 307-324. [CrossRef]

61. Butt, A.M.; Jones, H.C.; Abbott, N.J. Electrical resistance across the blood-brain barrier in anaesthetized rats: A developmental study. J. Physiol. 1990, 429, 47-62. [CrossRef] [PubMed]

62. Lippmann, E.S.; Al-Ahmad, A.; Azarin, S.M.; Palecek, S.P.; Shusta, E.V. A retinoic acid-enhanced, multicellular human blood-brain barrier model derived from stem cell sources. Sci. Rep. 2014, 4, 4160. [CrossRef] [PubMed]

63. Rempe, R.; Cramer, S.; Huwel, S.; Galla, H.J. Transport of Poly(n-butylcyano-acrylate) nanoparticles across the blood-brain barrier in vitro and their influence on barrier integrity. Biochem. Biophys. Res. Commun. 2011, 406, 64-69. [CrossRef] [PubMed]

64. Kreuter, J.; Ramge, P.; Petrov, V.; Hamm, S.; Gelperina, S.E.; Engelhardt, B.; Alyautdin, R.; von Briesen, H.; Begley, D.J. Direct evidence that polysorbate-80-coated poly(butylcyanoacrylate) nanoparticles deliver drugs to the CNS via specific mechanisms requiring prior binding of drug to the nanoparticles. Pharm. Res. 2003, 20, 409-416. [CrossRef] [PubMed]

65. Rankovic, Z. CNS Drug Design: Balancing Physicochemical Properties for Optimal Brain Exposure. J. Med. Chem. 2015, 58, 2584-2608. [CrossRef] [PubMed]

66. Wong, A.D.; Ye, M.; Levy, A.F.; Rothstein, J.D.; Bergles, D.E.; Searson, P.C. The blood-brain barrier: An engineering perspective. Front. Neuroeng. 2013, 6, 7. [CrossRef] [PubMed]

67. Saraiva, C.; Praca, C.; Ferreira, R.; Santos, T.; Ferreira, L.; Bernardino, L. Nanoparticle-mediated brain drug delivery: Overcoming blood-brain barrier to treat neurodegenerative diseases. J. Controll. Release 2016, 235, 34-47. [CrossRef] [PubMed]

68. Kuo, Y.C.; Wang, C.C. Electrophoresis of human brain microvascular endothelial cells with uptake of cationic solid lipid nanoparticles: Effect of surfactant composition. Colloids Surf. B 2010, 76, 286-291. [CrossRef]

69. Patil, S.; Sandberg, A.; Heckert, E.; Self, W.; Seal, S. Protein adsorption and cellular uptake of cerium oxide nanoparticles as a function of zeta potential. Biomaterials 2007, 28, 4600-4607. [CrossRef]

70. Zabara, M.; Vasheghani-Farahani, E.; Hosseinkhani, H.; Shojaosadati, S.; Soleimani, M. Fabrication and characterization of a new MRI contrast agent based on a magnetic dextran-spermine nanoparticle system. Iran. Polym. J. 2012, 21, 239-251.

71. Huang, J.; Zhong, X.; Wang, L.; Yang, L.; Mao, H. Improving the magnetic resonance imaging contrast and detection methods with engineered magnetic nanoparticles. Theranostics 2012, 2, 86-102. [CrossRef] [PubMed]

72. Estelrich, J.; Sánchez-Martín, M.J.; Busquets, M.A. Nanoparticles in magnetic resonance imaging: From simple to dual contrast agents. Int. J. Nanomed. 2015, 10, 1727-1741. [CrossRef] 
73. Wu, P.-C.; Shieh, D.-B.; Hsiao, H.-T.; Wang, J.C.-F.; Lin, Y.-C.; Liu, Y.-C. Magnetic field distribution modulation of intrathecal delivered ketorolac iron-oxide nanoparticle conjugates produce excellent analgesia for chronic inflammatory pain. J. Nanobiotechnol. 2018, 16, 49. [CrossRef] [PubMed]

74. Salimi, A.; Nadri, S.; Ghollasi, M.; Khajeh, K.; Soleimani, M. Comparison of different protocols for neural differentiation of human induced pluripotent stem cells. Mol. Biol. Rep. 2014, 41, 1713-1721. [CrossRef] [PubMed]

75. Song, B.; Sun, G.; Herszfeld, D.; Sylvain, A.; Campanale, N.V.; Hirst, C.E.; Caine, S.; Parkington, H.C.; Tonta, M.A.; Coleman, H.A.; et al. Neural differentiation of patient specific iPS cells as a novel approach to study the pathophysiology of multiple sclerosis. Stem Cell Res. 2012, 8, 259-273. [CrossRef]

76. Cao, S.-Y.; Hu, Y.; Chen, C.; Yuan, F.; Xu, M.; Li, Q.; Fang, K.-H.; Chen, Y.; Liu, Y. Enhanced derivation of human pluripotent stem cell-derived cortical glutamatergic neurons by a small molecule. Sci. Rep. 2017, 7, 3282. [CrossRef] [PubMed]

77. Juopperi, T.A.; Kim, W.R.; Chiang, C.H.; Yu, H.; Margolis, R.L.; Ross, C.A.; Ming, G.L.; Song, H. Astrocytes generated from patient induced pluripotent stem cells recapitulate features of Huntington's disease patient cells. Mol. Brain 2012, 5, 17. [CrossRef]

78. Chung, S.Y.; Kishinevsky, S.; Mazzulli, J.R.; Graziotto, J.; Mrejeru, A.; Mosharov, E.V.; Puspita, L.; Valiulahi, P.; Sulzer, D.; Milner, T.A.; et al. Parkin and PINK1 Patient iPSC-Derived Midbrain Dopamine Neurons Exhibit Mitochondrial Dysfunction and alpha-Synuclein Accumulation. Stem Cell Rep. 2016, 7, 664-677. [CrossRef]

79. Wattanapanitch, M.; Klincumhom, N.; Potirat, P.; Amornpisutt, R.; Lorthongpanich, C.; U-pratya, Y.; Laowtammathron, C.; Kheolamai, P.; Poungvarin, N.; Issaragrisil, S. Dual small-molecule targeting of SMAD signaling stimulates human induced pluripotent stem cells toward neural lineages. PLoS ONE 2014, 9, e106952. [CrossRef]

80. Du, Z.-W.; Chen, H.; Liu, H.; Lu, J.; Qian, K.; Huang, C.-L.; Zhong, X.; Fan, F.; Zhang, S.-C. Generation and expansion of highly pure motor neuron progenitors from human pluripotent stem cells. Nat. Commun. 2015, 6, 6626. [CrossRef]

81. Zhu, Y.; Wan, S.; Zhan, R.Y. Inducible pluripotent stem cells for the treatment of ischemic stroke: Current status and problems. Rev. Neurosci. 2012, 23, 393-402. [CrossRef] [PubMed]

82. Chambers, S.M.; Fasano, C.A.; Papapetrou, E.P.; Tomishima, M.; Sadelain, M.; Studer, L. Highly efficient neural conversion of human ES and iPS cells by dual inhibition of SMAD signaling. Nat. Biotechnol. 2009, 27, 275-280. [CrossRef] [PubMed]

83. Frega, M.; van Gestel, S.H.C.; Linda, K.; van der Raadt, J.; Keller, J.; Van Rhijn, J.-R.; Schubert, D.; Albers, C.A.; Nadif Kasri, N. Rapid Neuronal Differentiation of Induced Pluripotent Stem Cells for Measuring Network Activity on Micro-electrode Arrays. J. Vis. Exp. 2017, 119, 54900. [CrossRef] [PubMed]

84. Busskamp, V.; Lewis, N.E.; Guye, P.; Ng, A.H.; Shipman, S.L.; Byrne, S.M.; Sanjana, N.E.; Murn, J.; Li, Y.; $\mathrm{Li}$, S.; et al. Rapid neurogenesis through transcriptional activation in human stem cells. Mol. Syst. Biol. 2014, 10, 760. [CrossRef] [PubMed]

85. Zhang, Y.; Pak, C.; Han, Y.; Ahlenius, H.; Zhang, Z.; Chanda, S.; Marro, S.; Patzke, C.; Acuna, C.; Covy, J.; et al. Rapid single-step induction of functional neurons from human pluripotent stem cells. Neuron 2013, 78, 785-798. [CrossRef] [PubMed]

86. Bibel, M.; Barde, Y.A. Neurotrophins: Key regulators of cell fate and cell shape in the vertebrate nervous system. Genes Dev. 2000, 14, 2919-2937. [CrossRef]

87. Chung, C.Y.; Lin, M.H.; Lee, I.N.; Lee, T.H.; Lee, M.H.; Yang, J.T. Brain-Derived Neurotrophic Factor Loaded PS80 PBCA Nanocarrier for In Vitro Neural Differentiation of Mouse Induced Pluripotent Stem Cells. Int. J. Mol. Sci. 2017, 18, 663. [CrossRef]

88. Patapoutian, A.; Reichardt, L.F. Trk receptors: Mediators of neurotrophin action. Curr. Opin. Neurobiol. 2001, 11, 272-280. [CrossRef]

89. Cheng, P.-L.; Song, A.-H.; Wong, Y.-H.; Wang, S.; Zhang, X.; Poo, M.-M. Self-amplifying autocrine actions of BDNF in axon development. Proc. Natl. Acad. Sci. USA 2011, 108, 18430-18435. [CrossRef]

90. Kumari, A.; Singla, R.; Guliani, A.; Yadav, S.K. Nanoencapsulation for drug delivery. EXCLI J. 2014, 13, 265-286. 
91. Kuo, Y.C. Loading efficiency of stavudine on polybutylcyanoacrylate and methylmethacrylatesulfopropylmethacrylate copolymer nanoparticles. Int. J. Pharm. 2005, 290, 161-172. [CrossRef] [PubMed]

92. Chung, C.Y.; Yang, J.T.; Kuo, Y.C. Polybutylcyanoacrylate nanoparticles for delivering hormone response element-conjugated neurotrophin-3 to the brain of intracerebral hemorrhagic rats. Biomaterials 2013, 34, 9717-9727. [CrossRef] [PubMed] 